\title{
Milk Processing Affects Structure, Bioavailability and Immunogenicity of $\beta$-lactoglobulin
}

\author{
Kerensa Broersen \\ Department of Applied Stem Cell Technologies, TechMed Centre, University of Twente, Postbus 217, \\ 7500 AE Enschede, The Netherlands; k.broersen@utwente.nl
}

Received: 10 June 2020; Accepted: 26 June 2020; Published: 3 July 2020

\begin{abstract}
Bovine milk is subjected to various processing steps to warrant constant quality and consumer safety. One of these steps is pasteurization, which involves the exposure of liquid milk to a high temperature for a limited amount of time. While such heating effectively ameliorates consumer safety concerns mediated by pathogenic bacteria, these conditions also have an impact on one of the main nutritional whey constituents of milk, the protein $\beta$-lactoglobulin. As a function of heating, $\beta$-lactoglobulin was shown to become increasingly prone to denaturation, aggregation, and lactose conjugation. This review discusses the implications of such heat-induced modifications on digestion and adsorption in the gastro-intestinal tract, and the responses these conformations elicit from the gastro-intestinal immune system.
\end{abstract}

Keywords: bovine milk; pasteurization; $\beta$-lactoglobulin; digestion; aggregation; lactosylation; gastro-intestinal immune system

\section{Introduction}

Milk of bovine origin is widely consumed at a global level. While bovine milk is a protein-rich beverage containing 30-36 g of total protein per liter, the precise composition of milk varies with animal breed, stage of lactation, age, and diet (reviewed in [1]). The most prominent proteins present in milk are the caseins consisting of $\alpha$-s1, $\alpha$-s2, and $\beta$ and $k$-caseins, and the whey proteins $\alpha$-lactalbumin and $\beta$-lactoglobulin. While the caseins are dispersed in the form of calcium-containing micelles, whey proteins are solubilized in the whey fraction. Apart from a rich source of proteins, bovine milk also contains the sugar lactose, an O- $\beta$-D-galactopyranosyl-(1 $\rightarrow 4)$-D-glucopyranose, and lipids, primarily in the form of triacylglycerols. Prior to consumption, raw milk directly derived from the animal is subjected to various processing steps that may affect its molecular constituents. This review describes the available literature investigating the effect of processing of bovine milk on the structure and bioavailability of the main whey protein $\beta$-lactoglobulin.

\section{2. $\beta$-Lactoglobulin Secretion, Structure, and Genetic Variants}

\section{1. $\beta$-Lactoglobulin is a Member of the Lipocalin Family}

$\beta$-Lactoglobulin is the predominant whey protein in bovine milk. After $\beta$-lactoglobulin was recognized to share structural similarities $[2,3]$ and homology $[4,5]$ with plasma retinol binding protein, both proteins were assigned to the extracellular lipocalin family $[5,6]$, together with mouse major urinary protein [7], insecticyanin [8], and $\alpha_{2 u}$-globulin [9]. The lipocalin family, in turn, is part of the structural superfamily of calycins that, apart from lipocalins, also includes fatty acid-binding proteins, bacterial metalloprotease inhibitors, avidins, and triabin, which is a serine protease inhibitor. Although the biological function of $\beta$-lactoglobulin remains a debated topic, lipocalins share structural motifs giving rise to the ability of $\beta$-lactoglobulin to bind to small hydrophobic ligands such as fatty acids, 
cholesterol, vitamin $D_{2}$, or carotenoids within its hydrophobic cavity $[10,11]$ in addition to a possible weak binding site elsewhere on the molecule [12] that is genetic variant-dependent and becomes exposed upon heat-induced denaturation [13]. Transport of small hydrophobic ligands has therefore been suggested as a potential biological role of $\beta$-lactoglobulin. $\beta$-Lactoglobulin naturally occurs as a non-covalently bound dimer and this dimerization was found to play a critical role determining the affinity of $\beta$-lactoglobulin to ligands [14]. Recently, the natural affinity of $\beta$-lactoglobulin for fatty acids and other hydrophobic ligands initiated its exploitation to facilitate its potential as a drug carrier [15-17]. Other suggested biological roles of $\beta$-lactoglobulin include neonatal passive immunity transfer or a role in metabolism of phosphate in the mammary gland as a result of its observed interaction with p-nitrophenyl phosphate [18].

\section{2. $\beta$-Lactoglobulin is Post-Translationally Modified and Secreted}

$\beta$-Lactoglobulin is produced in the epithelial cells of the mammary gland. Pre- $\beta$-lactoglobulin is synthesized on membrane-bound polysomes [19] and contains a highly conserved signal peptide [20,21], destining this protein for its secretion. Upon trafficking from the ER to the Golgi for continued processing, pre- $\beta$-lactoglobulin comes across the sugar lactose which is generated in the trans-Golgi complex. Water buffalo $\beta$-lactoglobulin has also been found to be subject to $\mathrm{N}$-acylation or $\mathrm{N}$-lauroylation [22] although these modifications have not been reported for bovine $\beta$-lactoglobulin. Milk is secreted from the bovine mammary gland upon fusion of lactose and milk protein-containing secretory vesicles with the apical plasma membrane [23]. Secretion of $\beta$-lactoglobulin from the mammary gland is regulated by the peptide hormone prolactin, of which the production is triggered in response to neuroendocrine reflex, and supported by other hormones such as insulin, cortisol, thyroid hormone, and oxytocin which acts on contractile cells surrounding the ducts and alveoli [24]. Prolactin signaling involves activation of a Janus kinase (JAK)-signal transducer and activator of transcription proteins (STAT) pathway inducing transcription of genes involved in lactogenesis (reviewed [25]).

\section{3. $\beta$-Lactoglobulin Fold is a $\beta$-Sheet Rich, Non-Covalently Coupled Homodimer}

Upon the publication of an isolation procedure of $\beta$-lactoglobulin from bovine milk [26], structural and physico-chemical studies ensued to identify the structural characteristics of this protein. These studies showed that $\beta$-lactoglobulin is an $18.3 \mathrm{kDa}, 162$ amino acid polypeptide (Figure 1) which folds into an eight-stranded antiparallel $\beta$-barrel, arranged into two groups of four strands, lined with hydrophobic residues to create a deep hydrophobic cavity with ligand binding affinity [10,11]. A three-turn $\alpha$-helix is attached to the outside of the barrel. A ninth $\beta$-strand lies at the exterior of the $\beta$-barrel and is involved in dimer formation [27]. The native molecule contains two intramolecular disulfide bonds (Cys106-Cys119 and Cys66-Cys160) and one free thiol group (Cys121). The free thiol group, Cys121, and the disulfide bond Cys106-Cys 119, are buried, whereas the other disulfide bond, Cys66-Cys160, is positioned on the outer surface in a mobile region of the molecule $[3,28]$. Between $\mathrm{pH} 5.5$ and 7.5, at room temperature, $\beta$-lactoglobulin mainly exists as a non-covalently linked dimer. By increasing the temperature, addition of SDS, or moving the $\mathrm{pH}$ further away from the isoelectric point of the protein, the dimer-monomer equilibrium is shifted towards the monomeric form [29]. 
(A)

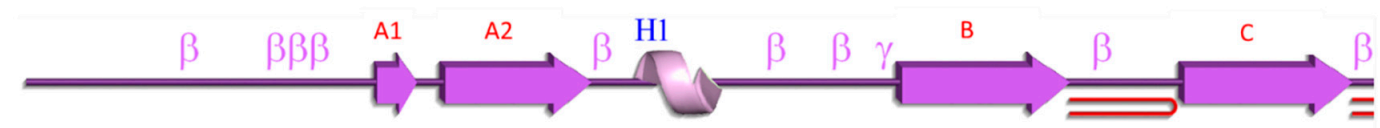

L I VTQTMKGLD I QKVAGTWYSLAMAASD I SLLDAQSAPLRVYVEELKPTPEGDLE I LLQKWE
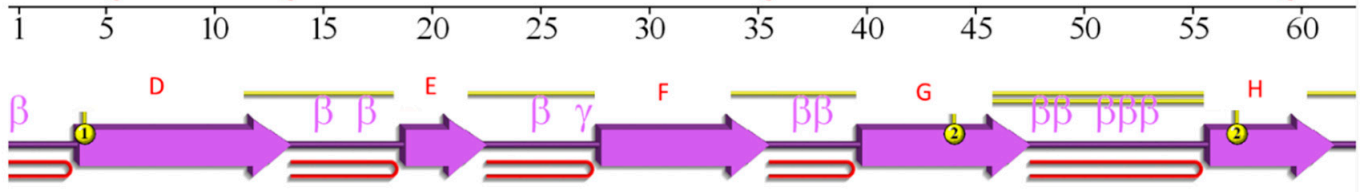

NDECAQKK I I AEKTK I PAVFK I DALNENKVLVLDTDYKKYLLFCMENSAEPEQSLVCQCLVR

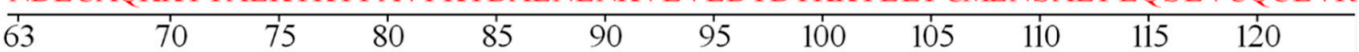

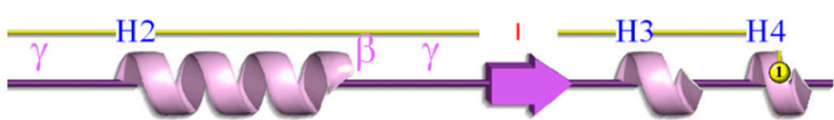

TPEVDDEALEKFDKALKAL PMH I RLSFNPTQLEEQCH I

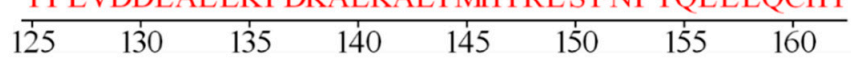

(B)

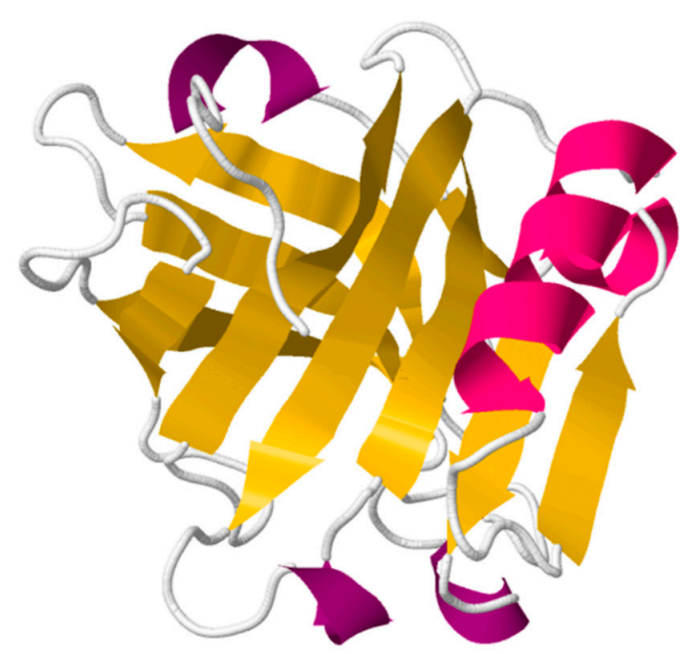

(C)

Figure 1. Structural features of bovine $\beta$-lactoglobulin. (A). Primary sequence of $\beta$-lactoglobulin variant A (B). (B). Diagram of secondary structural features of $\beta$-lactoglobulin. H1-H4, helical segments; A1-I, beta sheets; $\beta$, beta turn; $\gamma$, gamma turn; (1) = (2); disulphide bonds. Figure generated using PDBsum, PDB ID 1BSO [30], (C). Crystal structure of monomer of bovine $\beta$-lactoglobulin monomer, PDB ID: 1BEB [28]. Image generated using RCSB PDB [31].

\section{4. $\beta$-Lactoglobulin Knows as Many as Ten Genetic Variants}

Some ten variants of bovine $\beta$-lactoglobulin have been identified, dependent on the animal breed, but the two major genetic variants are designated as A and B. The primary structures of these variants differ at residues 64 , at which an aspartic acid in variant $A$ is a glycine in variant $B(A / B: D 64 G)$, and 118, 
at which the valine in variant $\mathrm{A}$ is an alanine in variant $\mathrm{B}(\mathrm{A} / \mathrm{B}$ : V118A) [32] (Figure 1). These two amino acid variations give rise to small differences in molecular weight and isoelectric point $[33,34]$. Even though this difference is minor, it has been shown to account for differences in stability upon exposure to heat [13,35-37], ligand binding [13], and susceptibility to proteolysis [38]. For example, bovine $\beta$-lactoglobulin variants $B$ and $C$, but not variant $A$, were observed to form high molecular weight aggregates at $\mathrm{pH} 6.7$ [37], and variant $\mathrm{B}$ was found to be more thermostable than variant $\mathrm{A}$ [13].

\section{Processing of Milk on $\beta$-Lactoglobulin Folding and Structure}

Upon collection of milk from a dairy farm the raw milk is subjected to a standardization step, by means of creaming, to generate a product with a defined level of fat. Creaming is generally performed at a temperature of $40^{\circ} \mathrm{C}$ using centrifugal force to separate the skim milk from the cream. Subsequently, the milk is standardized to a predefined fat level by recombining the skim milk and cream. The standardized milk is then treated to extend the shelf life by heat-mediated removal of pathogenic microorganisms. While specific heating conditions may vary between dairy suppliers and countries, minimal heating conditions have been defined by the heat resistance of the pathogen Coxiella burnetii, which was identified in 1950 in an epidemiological study relating raw milk consumption to the occurrence of $Q$ fever [39]. For example, the process of pasteurization may involve heating at $85^{\circ} \mathrm{C}$ for 2 to $3 \mathrm{~s}$ or maintaining the milk at a temperature of $63-66^{\circ} \mathrm{C}$ for $30 \mathrm{~min}$. Sterilization is performed at higher temperatures of $107-130^{\circ} \mathrm{C}$; the milk is maintained at this temperature for $8 \mathrm{~min}$ up to $40 \mathrm{~min}$. Other types of heating raw milk may be subjected to ultra high temperature treatment, which involves either steam injection or indirect heating at temperatures up to $145{ }^{\circ} \mathrm{C}$ for approximately $4 \mathrm{~s}$ [40]. Naturally, these processing conditions will impact the heat-sensitive biomacromolecules that milk is made up of. The stages of liquid milk processing and a summary of the experimentally-validated modifications in $\beta$-lactoglobulin as a consequence of processing are summarized in Figure 2.

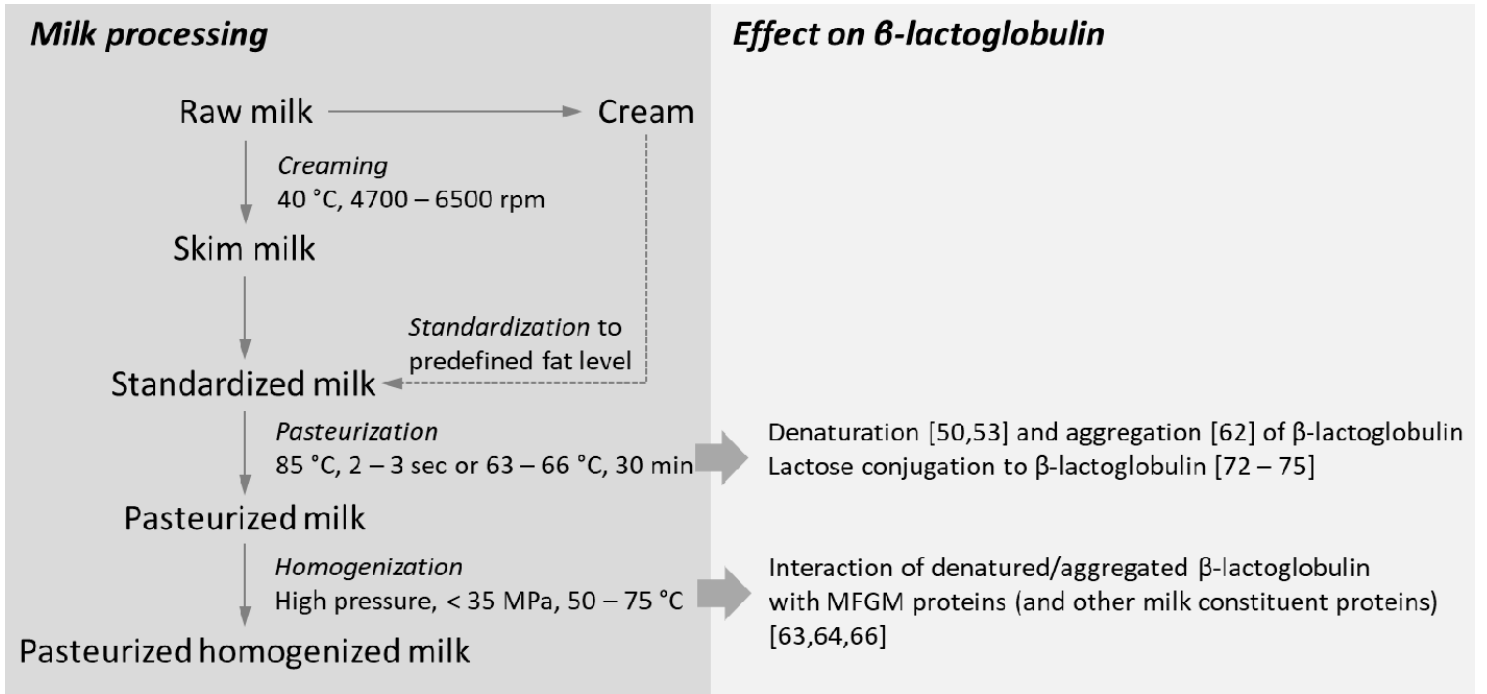

Figure 2. Processing of milk involves various steps, including creaming, pasteurization, and homogenization, which may impact $\beta$-lactoglobulin conformation and interaction with milk constituent proteins. The numbers in this image refer to publications in the reference list.

\subsection{Impact of Heat-Processing on $\beta$-Lactoglobulin Structure}

\subsubsection{Denaturation and Molten Globule State}

Bovine $\beta$-lactoglobulin is a globular protein that undergoes conformational changes as a function of $\mathrm{pH}$ or heat. While the native non-covalently bound dimeric structure of $\beta$-lactoglobulin is thermodynamically the most stable state in unprocessed milk with a small fraction occupying 
metastable partially unfolded monomeric states, heating and other types of processing and conditions can reportedly shift this relationship [41-44] as a result of dissociation of the hydrogen bond network [45]. For example, using sedimentation velocity analysis it was reported that $\beta$-lactoglobulin acquires monomer-dimer equilibrium at $100 \mathrm{mM} \mathrm{NaCl}$ and $\mathrm{pH} 2.5$ [41]. Initially $\beta$-lactoglobulin conformational shifts upon heating involve destabilization and partial unfolding of its globular structure to expose histidine, tyrosine, and tryptophan residues to the solvent [46] and increasing reactivity of the buried thiol group [47]. These limited and reversible conformational changes are followed by dissociation of intramolecular interactions and occupation of a partially unfolded, so-called molten globule state [48], reviewed in [49], which is also populated upon refolding of $\beta$-lactoglobulin [50], yielding exposure of the thiol group and the buried hydrophobic core of the protein [51]. While initial conformational transitions occur at temperatures as low as $40^{\circ} \mathrm{C}$ [52], fully denatured $\beta$-lactoglobulin is only observed at temperatures exceeding $130^{\circ} \mathrm{C}$ [53-55], indicating that the denaturation process of $\beta$-lactoglobulin can be described as a multistep mechanism. Generally, the midpoint of transition, at which abrupt large-scale loss of $\alpha$-helix structural elements is observed, is approximately $65{ }^{\circ} \mathrm{C}$ [55], depending on environmental conditions.

\subsubsection{Partially Denatured $\beta$-Lactoglobulin is Prone to Aggregation}

The partially denatured $\beta$-lactoglobulin protein molecule has been widely reported to be prone to thiol/disulfide exchange reactions, leading to its covalent aggregation, with non-covalent interactions playing a minor role [56-64]. A quantitative kinetic model that describes the irreversible aggregation of $\beta$-lactoglobulin as a function of thiol/disulfide exchange reactions was reported under low salt, neutral $\mathrm{pH}$ conditions upon heating at a temperature of $60-75^{\circ} \mathrm{C}$ [64]. Based on radical polymerization reactions, initiation, propagation, and termination steps were defined, translating into exposure of a free sulfhydryl group, a thiol/disulfide exchange reaction, and the reaction of two reactive intermediates, respectively. Studies like these have been highly instrumental in driving forward our understanding of the denaturation and aggregation of $\beta$-lactoglobulin in test tube conditions, which, however, in many cases do not resemble the complex environment in the presence of lipids, lactose, and other proteins and conditions in milk. For example, it has been shown that $\beta$-lactoglobulin can interact with other milk constituents, such as $\alpha$-lactalbumin, caseins, and bovine serum albumin, lactose, and lipids, which remarkably changes $\beta$-lactoglobulin behavior. The impacts of such interactions on $\beta$-lactoglobulin behavior are discussed in Section 5 .

\subsection{Homogenization Induces Disruption of the Milk Fat Globule Membrane}

Upon secretion of cytoplasmic milk fat globules, the vesicle is surrounded by an additional layer of plasma membrane, resulting in a phospholipid trilayer of which the outer layer is associated with plasma membrane-derived proteins and other biomolecular constituents termed the milk fat globule membrane (MFGM). Milk lipid globules vary in size from 0.1 to $20 \mu \mathrm{m}$ and are secreted by lactocytes, specialized epithelial cells residing in the mammary alveolus. Creaming is the process of gravity separation of these milk fat globules, or cream, from the skim milk observed in unhomogenized milk. To prevent creaming, homogenization is used; it acts by disrupting the MFGM and reducing the size of these lipid globules to an average of $1 \mu \mathrm{m}$, thereby reducing their tendency to cause creaming $[65,66]$. The process of homogenization generally involves heating of the raw milk to a temperature of $40^{\circ} \mathrm{C}$ followed by passing of the milk through a small-pore sized opening. While some studies show negligible effects of homogenization on structure and digestibility of $\beta$-lactoglobulin [67], one study showed that homogenization affects intestinal pancreatin-mediated digestion of raw and pasteurized whole milk. It was suggested that the MFGM-disrupting action of homogenization allows interaction with milk constituent proteins, resulting in their partial resistance against the enzymes trypsin and chymotrypsin [68]. In line with this suggestion, $\beta$-lactoglobulin was shown to interact with MFGM proteins but both homogenization and heat processing are prerequisites for this binding to occur [66]. The identified disulfide bond-mediated interaction between MFGM proteins and $\beta$-lactoglobulin 
supports the idea that cysteine residues that are largely buried within the hydrophobic core of the native protein require exposure by means of heat-induced unfolding [65]. Upon intestinal digestion, the bile salts are considered to replace proteins and peptides from the surface of milk lipid globules [69]. The interaction of $\beta$-lactoglobulin with MFGM proteins will be further discussed in Section 5 .

\subsection{Amino Acid Modifications}

\subsubsection{The Maillard Reaction}

Heat exposure of proteins in the presence of carbonyl compounds, such as reducing sugars, induces a complex non-enzymatic browning reaction termed the Maillard reaction [70]. In this reaction a reducing sugar targets the $\varepsilon$-amino group of lysine or the $\mathrm{N}$-terminal group of a protein to form Amadori or Heyn's rearrangement products. As originally described by Hodge in 1953 [71], the advanced stages of the Maillard reaction involve degradation of the Amadori (1-amino-1-deoxy-2-ketose) and Heyn's products via a range of pathways, depending on the conditions under which the reaction takes place, involving Schiff bases, Strecker degradation, or fission products, ultimately giving rise to melanoidins, brown nitrogenous polymers, and copolymers thereof [72,73], thereby affecting sensory properties of the processed milk.

\subsubsection{Heating Affects the Degree of Lactose Conjugation to $\beta$-Lactoglobulin}

Lactose is a reducing sugar present in milk that was shown, using mass spectrometry analysis, to conjugate to $\beta$-lactoglobulin upon heating by means of the Maillard reaction $[74,75]$ reducing the number of available free lysine residues. While $\beta$-lactoglobulin in raw milk was found to also be lactosylated and even dilactosylated to some extent [76], processing of milk by means of heat treatment was shown to increase lactose conjugation. The degree of lysine modification depends on the intensity of the heat treatment [76]: longer incubation times [77] at higher temperatures result in more extensive conjugation of $\beta$-lactoglobulin, and vice versa. Using reverse phase liquid chromatography-mass spectrometry, or LC-MS, it was found that the pattern of lactosylation of $\beta$-lactoglobulin is indicative of the extent of the heat treatment milk has been subjected to [78]. Many of the lactosylation sites of $\beta$-lactoglobulin in commercially available pasteurized milk have now been identified and include $\mathrm{K} 8$, K14, K47 [74,79,80], K60, K69, K75, K77, K83, K91 [79-81], K100 [74], K101, and K135 [75,76]. At the same time, the complexity of the reaction dictates that each individual reaction is regulated differentially at different temperatures and alternative degradation pathways of the formed intermediates prevail in a temperature-dependent manner [82], resulting in a heterogeneous reaction mixture of $\beta$-lactoglobulin conjugated forms.

\subsubsection{Effects of $\beta$-Lactoglobulin Glycation on Structure and Aggregation}

Glycosylation affects protein thermal stability [83-86]. Upon low degrees of conjugation of glucose or fructose to $\beta$-lactoglobulin, we and others observed that, while $\beta$-lactoglobulin became more resistant to denaturation upon heating [87-90], glucose conjugation resulted in loss of stability under conditions of chemical-induced unfolding using urea [91]. These two seemingly contradicting results were later reconciled in a publication which showed that glucose conjugation to $\beta$-lactoglobulin lowered the heat capacity change of unfolding [92]. In extension to this observation, conjugation of $\beta$-lactoglobulin with $\alpha$-dicarbonyl compounds, a Maillard reaction intermediate [93], or glucose [94], was shown to inhibit fibril growth. At the same time, published observations showed that denaturation and initial stages of aggregation of $\beta$-lactoglobulin may actually be accelerated upon conjugation with reducing sugars, while the elongation of amyloid-like fibrils was reduced by inhibition of disulfide bond formation [95], increased steric hindrance [96,97], or disruption of hydrophobic interactions favoring aggregation [97]. Differences in degrees and site of reducing sugar conjugation to $\beta$-lactoglobulin and the Maillard reaction conditions may well explain these seemingly contradictory results by affecting native $\beta$-lactoglobulin conformation to a different extent. In a study investigating the aggregation-at 
an elevated temperature and $\mathrm{pH} 2$-of $\beta$-lactoglobulin as a function of glucose or lactose conjugation, different lysine residues were shown to vary in their susceptibility to glycation to either reducing sugar which, in turn, differentially affected the different stages of the aggregation process [97].

\section{A Special Type of Fold: $\beta$-Sheet Motif Spherical Particles and Amyloids}

Self-assembly states or aggregates of $\beta$-lactoglobulin can be formed upon heat-denaturation and refolding concurrent with the formation of non-native intermolecular interactions. The ability to form such aggregates is both genetically variant and $\mathrm{pH}$-dependent [37]. Aggregating proteins were first recognized in the light of a pathogenic species involved in Alzheimer's disease, transmissible spongiform encephalopathies, Creutzfeldt-Jakob disease, type II diabetes, Parkinson's disease, and Huntington's disease [98-102]. Later studies showed that aggregate formation is not limited to the proteins related to these pathologies but that the ability of proteins to adopt an aggregated state is a shared feature of proteins independent of their amino acid sequences [103], reviewed in [104]. Additionally, while proteins are known to resume their fully folded state upon removal of heat, partial unfolding of $\beta$-lactoglobulin upon heating may expose reactive groups kinetically driving the formation of intermolecular interactions. The fate of a protein's folding upon removal of heat then depends on the relationship between the rates of aggregation and refolding. Refolding of partially unfolded protein molecules into intermolecular cross- $\beta$-sheet structures has been central to one of the hypotheses by which $\beta$-lactoglobulin is thought to self-assemble into aggregates [105]. The concentration dependence of the aggregation rate than dictates the outcome of heating followed by cooling [106]. Additionally, while $\beta$-lactoglobulin concentrations may not be very high in fluid milk, it is likely that $\beta$-lactoglobulin may encounter other proteins that induce its co-aggregation (see also Section 5). Other than protein concentration, the extent of aggregation and the aggregate morphology are dependent on hydrophobicity, duration of heat treatment, and electrostatics [107]. While $\beta$-lactoglobulin was shown to populate two distinct aggregate morphologies as a function of $\mathrm{pH}$, the fibrils formed are heterogeneous [108]. Near the iso-electric point of 5.2 and a transition temperature of $70-90^{\circ} \mathrm{C}$, the aggregate morphology of $\beta$-lactoglobulin is dominated by $100-1500 \mathrm{~nm}$ radii spherical aggregates with low $\beta$-sheet content [109-111]. On the other hand, fibrillar cross $\beta$-sheet-rich motif morphologies are found for $\beta$-lactoglobulin that has been incubated at a $\mathrm{pH}$ of 2 , far removed from its iso-electric point [109-112]. These observations indicate that, even though the driving force for aggregation is ultimately overcome, electrostatics and charge density determine the morphological outcome of the reaction. Furthermore, at $\mathrm{pH} 2$ it was shown that $\beta$-lactoglobulin amyloid fibrils are not composed of full-length monomers of $\beta$-lactoglobulin, but instead that hydrolysis-mediated peptide fragments self-assemble into oligomers that further elongate into fibrils [113]. A review summarizing the different morphological appearances of $\beta$-lactoglobulin aggregates and their molecular make-up has been published before [114]. Many insights on $\beta$-lactoglobulin aggregation have been rendered using in vitro studies making use of purified forms of $\beta$-lactoglobulin. In milk upon pasteurization also, aggregation of $\beta$-lactoglobulin [115,116] into large $>670 \mathrm{kDa}$ assemblies [116] has been reported. For example, while aggregated $\beta$-lactoglobulin in raw milk was not detected, processed milk led to loss of native fold $\beta$-lactoglobulin concurrent with conversion into aggregates, as detected by native and SDS-PAGE depending on the processing conditions [115].

\section{Interaction of $\beta$-Lactoglobulin with other Milk Proteins}

Mixtures of proteins isolated from milk have been shown to interact in test tube conditions upon heating. For example, the presence of $\beta$-lactoglobulin induced the aggregation of $\alpha$-lactalbumin, presumably by interaction at the unfolded state, to form mixed protein gels [117]. In skim milk, $\beta$-lactoglobulin was found to interact with casein micelles [118], $k$-casein $[119,120], \alpha$-lactalbumin [121], or MFGM proteins $[65,66]$. 


\subsection{Interaction of $\beta$-Lactoglobulin with $\alpha$-Lactalbumin}

Besides $\beta$-lactoglobulin, $\alpha$-lactalbumin is another major whey protein component in bovine milk containing four disulfide bonds but no free thiol groups [122]. As a regulatory subunit of the enzyme lactose synthase, $\alpha$-lactalbumin acts by regulating the conjugation of glucose to the enzyme $\beta 1,4$-galactosyltransferase mediating the formation of lactose [123]. Depending on the presence of calcium, $\alpha$-lactalbumin assumes a moderately stable holo or native calcium-bound or unstable apo calcium-free conformation $[124,125]$. Compared to $\beta$-lactoglobulin, $\alpha$-lactalbumin has demonstrated some resistance to the formation of aggregates. The lack of free thiol in $\alpha$-lactalbumin to form intermolecular disulfide bonded aggregates has been proposed to contribute to this behavior and this can be circumvented by the exposure of $\beta$-lactoglobulin and $\alpha$-lactalbumin mixtures to high pressure [126] or oil/water interface $[127,128]$ conditions in which the free thiol group of $\beta$-lactoglobulin acts as a triggering agent forming mixed disulfide bonded $\beta$-lactoglobulin/ $\alpha$-lactalbumin oligomers [126]. A certain degree of temperature dependency of $\alpha$-lactalbumin/ $\beta$-lactoglobulin co-aggregation has been reported. For example, while temperature treatment of $72{ }^{\circ} \mathrm{C}$ for $15 \mathrm{~s}$ did not show formation of SDS-stable interactions between $\alpha$-lactalbumin and $\beta$-lactoglobulin [129], exposure to high temperature led to detection of $\alpha$-lactalbumin and $\beta$-lactoglobulin mixed aggregates stabilized by means of disulfide bond interchange [129-132] and hydrophobic interactions [132]. Extensive aggregation can develop into a gel state, which is a three-dimensional arrangement of molecules with water holding capacity. $\beta$-Lactoglobulin is capable of forming gels and the ability to do so at $\mathrm{pH} 2$ was found to be induced by the presence of $\alpha$-lactalbumin [133].

\subsection{Interaction of $\beta$-Lactoglobulin with Caseins}

Caseins in milk are generally found assembled into large structures termed casein micelles. One of the caseins in bovine milk is k-casein, which is an amphiphilic protein associated with the surfaces of casein micelles by means of hydrophobic interactions in bovine milk masking the cysteine residues, while $\mathrm{k}$-casein hydrophilic regions extend away from the micelle and play a micelle stabilizing role $[134,135]$. After the original discovery that $k$-casein and $\beta$-lactoglobulin form complexes upon heating of milk [136], in some cases also found to involve $\alpha$-lactalbumin [137-140], further studies showed that this interaction is mainly disulfide bond driven [141]. Investigations on the specific residues involved in the reaction identified that cysteine $121 \beta$-lactoglobulin interacts with cysteine 88 of $\mathrm{k}$-casein upon heat treatment, although other cysteine residues were observed to be involved as well, depending on the incubation conditions [142-145]. Casein micelles were found to either dissociate upon interaction with $\beta$-lactoglobulin [135] or to precede interaction with denatured $\beta$-lactoglobulin [146]. In turn, an increased rate of native protein conversion into small aggregates with inhibited progression into larger aggregates was reported for $\mathrm{k}$-casein-associated $\beta$-lactoglobulin [145] with a heterogeneous range of aggregated complexes being formed [120,141-143]. There has been some reported inconsistency in the aggregate size of $\beta$-lactoglobulin to be involved in the complexation with $\mathrm{k}$-casein, with some reporting that aggregation of $\beta$-lactoglobulin is a prerequisite for interaction with $\kappa$-casein [141,147], while others suggest that denatured [148] or small aggregated [149] forms of $\beta$-lactoglobulin are required for this interaction. It would make sense intuitively to suggest that the $\beta$-lactoglobulin fold at least requires some degree of unfolding to expose the thiol group that was previously identified to play a role in the disulfide bond coupling of $\beta$-lactoglobulin to $k$-casein. Although many of the studies investigating the interaction between $k$-casein and $\beta$-lactoglobulin were based on purified or partially purified proteins, it was shown that in heated bovine milk also, similar patterns for complexation were identified [150]. A review further detailing the heat-induced interaction between whey protein fragments and $\mathrm{k}$-casein has been published before [151]. 


\subsection{Interaction of $\beta$-Lactoglobulin with MFGM Proteins}

MFGM proteins consist of various proteins derived from the plasma membrane of the secretory epithelial cells of the mammary gland. This origin results in a complex mixture of major proteins entailing the glycoprotein lactadherin (periodic acid Schiff (PAS) 6/7), xanthine dehydrogenase/oxidase, periodic acid Schiff III, acidophilin, mucin MUC1, butyrophilin, fatty-acid binding protein (FABP), and cluster of differentiation (CD) 36, in addition to minor fractions of enzymes, cytoplasmic proteins, immunoglobulins, major histocompatibility complex (MHC) molecules (reviewed in [152]), and apolipoproteins [153]. $\beta$-Lactoglobulin was reported to be associated with MFGMs by covalent disulfide bond interaction in a few occasions $[153,154]$. Particularly under conditions of heating of milk between 65 and $85{ }^{\circ} \mathrm{C}$, $\beta$-lactoglobulin complexes with MFGM proteins, presumably in response to unfolding of $\beta$-lactoglobulin (reviewed in [65]). Consistent with this finding, buttermilk-derived MFGM isolates contained large amounts of $\beta$-lactoglobulin, along with caseins and $\alpha$-lactalbumin [154].

\section{Relation between $\beta$-Lactoglobulin Fold and Digestion and the Gastro-Intestinal Immune System}

Processing-induced changes of $\beta$-lactoglobulin in milk, such as unfolding, aggregation, and lactosylation, may impact digestion, adsorption, and the response of the gastro-intestinal immune system. For example, the extent of heating was observed to affect digestibility of proteins as a function of denaturation, aggregation, or lactosylation [155].

\subsection{Protein Digestion and Absorption in the Gastro-Intestinal Tract-An Overview}

Food-derived proteins are digested in the gastrointestinal tract. Susceptibility of proteins to digestion depends on isoelectric point [156] and structural organization. Once a dairy product arrives in the stomach, hydrochloric acid in gastric juices drive the $\mathrm{pH}$ in the gastric environment below 2, initiating the digestion of proteins mediated by the enzyme pepsin. Protein digestion involves the hydrolysis of peptide bonds, resulting in the formation of peptide fragments that progressively become shorter upon increased enzymatic processing. After partial digestion in the stomach into large peptide fragments, the majority of further protein digestion and absorption occurs in the duodenum by exposing the large peptide fragments to a mixture of pancreatic proteolytic enzymes chymotrypsin, carboxypeptidase, and trypsin to further hydrolyze peptide bonds, to produce smaller peptide fragments. Intestinal epithelial cells adhered brush border enzymes that include dipeptidases and amino peptidases and then hydrolyze the remaining peptide bonds further to generate even smaller fragments consisting of tripeptides, dipeptides, and individual amino acids. To aid absorption, the remaining tripeptides and dipeptides are taken up by the gastrointestinal epithelial cells by means of a cotransporter with hydrogen. Inside the cell, intracellular peptidases are active to hydrolyze any remaining peptide bonds and generate individual amino acids. Luminal individual amino acids are taken up by epithelial cells using a $\mathrm{Na}^{+}$channel. These individual amino acids can then diffuse into the blood stream from which they are transported to the liver. While many enzymes used in in vitro digestion studies of $\beta$-lactoglobulin are from porcine origin, it was shown that human and porcine pepsin share similar specificity but differ in rate of activity [157].

\subsection{Native $\beta$-Lactoglobulin is Largely Resistant to Gastric Digestion}

The native $\beta$-lactoglobulin fold is subject to the so-called Tanford transition: a reversible conformational change that takes place in the EF loop (Figure 1B) when varying the $\mathrm{pH}$ between 6 and 8 . While the $\mathrm{pH}$ of fresh milk is 6.5 to 6.75 , upon ingestion and transport to the gastric cavity, milk proteins are exposed to a lowering in $\mathrm{pH}$, giving rise to accumulation of a closed loop conformation of $\beta$-lactoglobulin [158]. Another $\mathrm{pH}$ driven conformational response of $\beta$-lactoglobulin to a lowering of $\mathrm{pH}$ is the dissociation of its two component dimers into monomers at $\mathrm{pH}$ values below 3 [159]. Prediction of cleavage sites in $\beta$-lactoglobulin upon exposure to gastric pepsin and 
trypsin in the duodenum leads to the identification of multiple sites susceptible to proteolysis by gastric pepsin (Figure 3). However, digestion of $\beta$-lactoglobulin upon exposure to gastro-intestinal enzymes is generally reported to be partial with a significant portion of the protein remaining intact after gastric digestion [160-163]. On the other hand, duodenal digestion, usually mimicked in vitro by exposure to $\mathrm{pH}$ 6.5, the enzyme trypsin, sometimes in the presence of pancreatic lipase and colipase, phosphatidyl choline vesicles, and bile salts, resulted in fragmentation of the protein with a low quantity of remaining intact protein $[160,164-168]$. In the presence of lipids $\beta$-lactoglobulin is more resistant against pancreatic proteolytic degradation, possibly as a result of its capacity to bind to lipid-like ligands stabilizing $\beta$-lactoglobulin conformation and limiting access to enzyme cleavage sites [160], similarly to $\alpha$-lactalbumin [169]. Most of these observations were made under conditions of in vitro static digestion, and while such systems provide valuable information on the susceptibility of proteins to gastro-intestinal degradation, other factors, such as microbe-derived enzyme activity, are generally not taken into consideration. Digestion being a process with dynamic factors, including peristalsis, in vitro dynamic models for digestion are increasingly being developed and used to provide additional insight into protein digestion processes with the aim of more accurately recapitulating the in vivo digestion processes [170]. In a study comparing a static and a dynamic digestion protocol with in vivo digestion in a pig model, protein hydrolysis patterns appeared very similar in all three models, but while digestion endpoints were similar, kinetics of the hydrolysis process upon in vitro dynamic digestion more closely resembled those of the in vivo model [171].

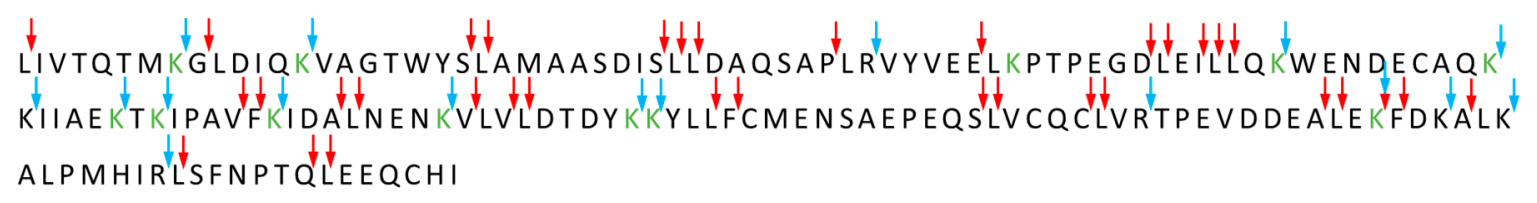

Figure 3. Predicted cleavage sites of pepsin at $\mathrm{pH} 1.3$ (red arrows), mimicking gastric digestion, and trypsin (blue arrows), mimicking intestinal digestion. Cleavage sites were predicted using the amino acid sequence of $\beta$-lactoglobulin A as input in ExPASy, using the tool PeptideCutter [172]. Lysine (K) residues indicated in green have previously been identified to be subject to lactosylation $[75,76]$.

\subsection{Digestion and Absorption of Denatured and Aggregated Proteins in the Gastrointestinal Tract}

Proteins with altered conformation as a result of processing may be subject to alternative digestion pathways or susceptibility. The effect of milk processing on digestibility has been systematically reviewed and denaturation was found to generally aid hydrolysis in the gastric cavity and affects gastric emptying (reviewed in [173]). Heat-mediated dissociation of dimeric $\beta$-lactoglobulin and unfolding leading to exposure of buried hydrophobic amino acids are considered to increase the accessibility to digestive enzymes such as pepsin [174-176]. While partial denaturation in the absence of extensive aggregation may increase susceptibility to enzymatic digestion as a result of exposure of (additional) cleavage sites, aggregation is generally thought to compact the protein structure to render such sites inaccessible. In line with this thought, it has been demonstrated that particularly the cores of fibrillar aggregates derived from prion proteins exert high levels of resistance against enzymatic breakdown [177]. The reported capacity of $\beta$-lactoglobulin to bind to lipid ligands and the suggested resistance of self-assembled $\beta$-lactoglobulin structures to proteolytic digestion have been exploited to investigate its use as an oral delivery system for improving the bioavailability of various hydrophilic and hydrophobic bioactive compounds, such as riboflavin and quercetin [178]. However, while heating of whey protein isolates was indeed shown to decrease pepsin-mediated digestibility [156], pure $\beta$-lactoglobulin fibrillar aggregates, generated upon heating at $80^{\circ} \mathrm{C}$ and $\mathrm{pH} 2$ or $\mathrm{pH} 7.4$, were found to be rapidly digested by pepsin [179]. Similarly, heating of isolated $\beta$-lactoglobulin at $90^{\circ} \mathrm{C}$ was shown to induce aggregation and increase in vitro gastric digestibility with differently sized aggregates exerting different degrees of susceptibility to proteolysis [168]. Interestingly, upon pepsin-mediated digestion in simulated gastric fluid, the generated peptide fragments were capable of re-association into newly 
formed fibrils $[180,181]$. It is possible that other constituents present in whey protein isolate, such as $\alpha$-lactalbumin, bovine serum albumin, lactose, or lipids, are responsible for the observed limited susceptibility of aggregates to pepsin-mediated digestion which is also in line with the observation that $\beta$-lactoglobulin may form co-aggregates with other whey proteins (see Section 5 ) and that the presence of lipids decreases enzymatic digestibility of $\beta$-lactoglobulin [160]. While many studies investigate pepsin-mediated digestion of $\beta$-lactoglobulin, the trypsin-mediated digestion of $\beta$-lactoglobulin aggregates is relatively seldomly studied. While aggregated $\beta$-lactoglobulin was shown to be targeted by trypsin, when studied at a $\mathrm{pH}$ of 9.1, the rate of digestion was comparatively slow compared to native $\beta$-lactoglobulin and the generated fragments were incapable of reaggregation [181].

\subsection{Digestion of Lactosylated $\beta$-Lactoglobulin}

Pepsin was reported to preferentially cleave at phenylalanine, tyrosine, tryptophan, or leucine [182]. At the same time, prediction of cleavage sites using the ExPASy tool PeptideCutter [172] suggests that trypsin preferentially targets arginine and lysine groups [182], indicating that lysine modification may well affect the digestibility of proteins. Experimentally observed lysine lactosylation sites $[75,76]$ also overlap with targeted cleavage sites for trypsin (Figure 3). It was indeed experimentally validated that lysine modification impairs susceptibility of proteins to enzymatic digestion (reviewed in [173,183-189]). Various mechanisms to explain impaired digestion have been suggested, including direct protection of lysine as a proteolytic target site, prevention of docking of proteolytic enzymes as a result of a modified lysine residue located immediately adjacent to an intended cleavage site, or by means of cross-linking with target residues [190].

\section{Response of the Gastro-Intestinal Immune System to Heat-Treated $\beta$-Lactoglobulin}

\subsection{Mucus Layer as the First Line of Physical Defense}

The immunological defense system of the gastrointestinal tract is composed of a mucosal layer that acts as first line of physical defense. The mucosal layer, which prevents the direct interaction of the gut epithelial layer with, for example, pathogenic bacteria, toxins, and other infectious agents, is composed of entangled forms of the glycoprotein mucin which is secreted by goblet cells. The gut's resident microbiome and the mucus layer were shown to interact and support each other's functioning by means of chemical interactions mediated by epithelial gene expression responses and innervation by the enteric nervous system. Some studies have investigated the diffusion of proteins and other molecules or particulates through the mucus layer. $\beta$-Lactoglobulin, and other proteins, can electrostatically interact with salivary mucins (reviewed in [191]), and bovine serum albumin, lysozyme, and $\alpha$-synuclein proteins were observed to reorganize mucin MUC5B-containing hydrogels [192]. The rate of diffusion appears to be dictated, apart from by interaction with components of the mucus layer, by particle size, as the pore size of intestinal mucus was found to approximate $100 \mathrm{~nm}$ [193]. For example, it has been observed that mucus allows diffusion of $100 \mathrm{~nm}$ latex beads, and diffusion of $500 \mathrm{~nm}$ beads was limited [194]. As spherical aggregates of $\beta$-lactoglobulin were reported to vary between 100 and $1500 \mathrm{~nm}$ in size [109-111], it is plausible that diffusion of such particles is limited and a function of efficient proteolytic processing prior to adsorption.

\subsection{Gut-Associated Lymphoid Tissue and Peyer's Patches}

Associated with the mucosal layer is the gut-associated lymphoid tissue (GALT) that is comprised of $\mathrm{T}$ and B lymphocytes, plasma cells, and macrophages organized into so-called Peyer's patches covered with epithelial microfold, or M, cells in the small intestine. The basal membrane of $\mathrm{M}$ cells is extensively folded but lack apical microvilli, and these cells are responsible for uptake of antigens by means of endocytosis or phagocytosis, after which the antigen is encapsulated into transport vesicles and trafficked across the cell for release at the basal surface which is generally associated with a B cell [195] and dendritic cells [196]. Upon release, a mucosal immune response or mucosal tolerance 
may be provoked. M cells were shown to be a prerequisite for mucosal immune response, as an impaired mucosal immune response was observed in a model system deficient in M cells [197]. Peyer's patch resident Th2 and Th3 cells respond to antigens by inducing their migration to the periphery and transforming growth factor (TGF)- $\beta$, interleukin (IL)-4, and IL-10 cytokine production [198-200]. The response of Peyer's patches to luminal antigens appears to be regulated by pathogen recognition receptors of which Nucleotide oligomerization domain 2 (Nod2) and toll-like receptors have been established to play a key role (reviewed in [201]).

\subsection{Uptake of $\beta$-Lactoglobulin by Microfold Cells}

A few transmembrane capture receptors have been identified to play a role in uptake recognition by $M$ cells, including the tight junction protein Claudin-4 [202] and glycoprotein 2 (gp2) [203], but currently none of those candidates have been specifically tested for recognition of $\beta$-lactoglobulin aggregates or other proteinaceous assemblies. At the same time, it is plausible to assume that uptake of $\beta$-lactoglobulin aggregates occurs via a similar pathway as has been previously identified for latex microparticles which were shown to be efficiently taken up by $\mathrm{M}$ cells before [204]. $\mathrm{M}$ cells were recently proposed to exert specialized uptake activity towards negatively charged microparticles [205], and both the diameter and electrostatic charge of $\beta$-lactoglobulin aggregates resemble those of such microparticles. Transcytosis of particular aggregates has remained an equally little-understood matter.

\subsection{Response of Gastrointestinal Lymphocytes to $\beta$-Lactoglobulin}

\subsubsection{Peyer's Patch Lymphocytes}

The response of Peyer's patches to pathogenic bacteria and viruses has been well-described [206,207]. At the same time, limited studies investigated the response of Peyer's patches to $\beta$-lactoglobulin. Exposure of human ileal Peyer's Patches to $\beta$-lactoglobulin induced the proliferation and activation of Peyer's patch resident lymphocytes, as indicated by increased expression of cluster of differentiation (CD) $4^{+}, \mathrm{CD} 8^{+}$, $\mathrm{CD} 25^{+}, \mathrm{C}-\mathrm{C}$ chemokine receptor type 5 (CCR5)—which is a Th1-associated chemokine receptor, and interferon (IFN)- $\gamma$ [208]. In line with these observations, IL-10 and IL-4 secretions were not induced by dietary $\beta$-lactoglobulin showing that the response of Peyer's patches from ileal origin to $\beta$-lactoglobulin is primarily Th1 type driven. Aggregation of proteins has been reported to modulate the intestinal immune response and Peyer's patches were found to play a role too. While the precise uptake, transcytosis, and delivery mechanism of aggregated proteins by $\mathrm{M}$ cells has not been investigated, some studies reported on Peyer's patch responses to various forms of $\beta$-lactoglobulin. While native $\beta$-lactoglobulin is primarily taken up through enterocytes [116], or, alternatively, was observed to drive a Th1 type response in Peyer's patches [208], pasteurization-induced aggregation of $\beta$-lactoglobulin reduces uptake by absorptive epithelial cells, and fluorescein isothiocyanate (FITC)-labeling of $\beta$-lactoglobulin and imaging of Peyer's patches using immunostaining showed that such aggregates are preferably taken up by Peyer's patches both in vitro using monolayers of Caco-2 cells, which is a human epithelial colorectal adenocarcinoma cell line, and in vivo in a mouse model [116]. Uptake of aggregated $\beta$-lactoglobulin by Peyer's patches was associated with an increased production of Th2-associated antibodies and cytokines such as IL-5, IL-13, and IFN- $\gamma[116]$.

\subsubsection{Lamina Propria-Associated Lymphocytes}

Apart from in Peyer's patches, lymphocytes are also diffusely distributed in the underlying connective tissue called lamina propria. Similarly to Peyer's patch resident lymphocytes, proliferation of lymphocytes associated with the jejunal lamina propria also was induced in vitro upon exposure to $\beta$-lactoglobulin [209]. $\beta$-Lactoglobulin-mediated proliferation of lamina propria $\mathrm{CD} 4^{+}$lymphocytes initially showed increased generation of IL-2, IL-10, IL-12, tumor necrosis factor (TNF)- $\alpha$, and IFN- $\gamma$. IFN- $\gamma$ induces the expression of surface markers on antigen presenting cells (APCs), which, in turn, generate the cytokine IL- 12 . IFN- $\gamma$ has been shown to induce IFN- $\gamma$ production in a CD2 signaling pathway-mediated manner [210]. 
The involvement of APCs was demonstrated as antibodies against CD2 or its ligand CD58 reduced $\beta$-lactoglobulin-mediated proliferation of lymphocytes. At the same time, prolonged exposure to $\beta$-lactoglobulin triggered suppressor activity [209]. While it is clear that native $\beta$-lactoglobulin modulates the proliferation and cytokine expression patterns of lymphocytes, whether and how lamina propria-resident lymphocytes respond to aggregated $\beta$-lactoglobulin has not been reported.

\subsection{Human Leukocyte Response to $\beta$-Lactoglobulin after Absorption}

Neutrophils are blood-residing polymorphonuclear leukocytes that are recruited to the intestinal lamina propria in response to a chemoattractant gradient generated by the monocytes present in the gut [211]. Once trafficked to the lamina propria or upon transepithelial migration into the intestinal lumen, neutrophils play a role in the gastrointestinal immune response by generating reactive oxygen species, cytokines, and antimicrobial peptides; eliminating pathogenic bacteria; and recruiting macrophages by secreting monocyte chemoattractants (reviewed in [212]), [213]. While the response of neutrophils to invading pathogenic bacteria has been well-established, reactivity toward whey proteins and aggregates thereof is less well known. $\beta$-Lactoglobulin was found to induce the generation and secretion of self-regulatory interleukin receptor 1 antagonist by neutrophils in vitro mediated by $\mathrm{p} 38$ MAPK, MAPK/ERK kinase, and NF-KB pathways, and to stimulate the neutrophilic production of inflammatory mediators IL- $1 \beta$, IL-8, IL-6, TNF- $\alpha$, and macrophage inflammatory proteins $1 \alpha$ and $1 \beta$ [214]. $\beta$-Lactoglobulin was also found to induce neutrophilic superoxide production and induce translocation of p47phox subunit of cytosolic NADPH-oxidase to the plasma membrane [215] which is required for activation of NADPH-oxidase-mediated superoxide production [216].

\section{Conclusions}

$\beta$-Lactoglobulin has been subject to intensive investigation efforts since its identification as a main whey protein component. While the biological function of this protein remains to be revealed, $\beta$-lactoglobulin was shown to be a highly complex protein molecule able of undergoing various transitions, such as the $\mathrm{pH}$-induced Tanford transition, thiol-disulfide reshuffling, and dimer-monomer conversion, while, at the same time, being able to populate various transient states such as the molten globule and various aggregated forms. $\beta$-Lactoglobulin is also subject to various types of modifications, such as lactosylation, and it is reported to interact with a number of other proteins present in milk. Many of these reported features of $\beta$-lactoglobulin are now known to be altered, to some degree, mediated by homogenization and heat-processing of milk aimed at extending stability and shelf-life of the perishable product. In turn, the different modifications $\beta$-lactoglobulin undergoes upon thermal processing have implications for the digestibility, bioavailability, and gastrointestinal response to $\beta$-lactoglobulin. These multi-facetted, dynamic, and transient short-lived characteristics of the various faces $\beta$-lactoglobulin can assume complicate the study of its physico-chemical and biochemical properties. In many instances, it turned out to be challenging, in part because of the dynamics of states, to unequivocally associate any of the reported biophysical and biochemical characteristics of $\beta$-lactoglobulin to biological responses upon ingestion. To address that, many researchers to date have succeeded in revealing some of the complex interactions and structural-biological features of $\beta$-lactoglobulin by working with isolated $\beta$-lactoglobulin fractions, away from the complex environment that liquid milk represents. In the future, we envision that studies into the behavior of $\beta$-lactoglobulin in milk may reveal further molecular insights in the workings of this multi-functional protein.

Author Contributions: K.B. performed the literature survey, wrote the manuscript and prepared the images. The author has read and agreed to the published version of the manuscript.

Funding: This research received no external funding.

Acknowledgments: Work on this topic in the laboratory of the author is financially supported by a grant from the “Nutricia Research Foundation," project number 2012-35.

Conflicts of Interest: The author declares no conflict of interest. 


\section{References}

1. Haug, A.; Høstmark, A.T.; Harstad, O.M. Bovine milk in human nutrition-A review. Lipids Health Dis. 2007, 6, 25. [CrossRef]

2. Newcomer, M.; Jones, T.; Aqvist, J.; Sundelin, J.; Eriksson, U.; Rask, L.; Peterson, P. The three-dimensional structure of retinol-binding protein. EMBO J. 1984, 3, 1451-1454. [CrossRef]

3. Papiz, M.Z.; Sawyer, L.; Eliopoulos, E.E.; North, A.C.T.; Findlay, J.B.C.; Sivaprasadarao, R.; Jones, T.A.; Newcomer, M.E.; Kraulis, P.J. The structure of $\beta$-lactoglobulin and its similarity to plasma retinol-binding protein. Nature 1986, 324, 383-385. [CrossRef] [PubMed]

4. Godovac-Zimmermann, J.; Conti, A.; Liberatori, J.; Braunitzer, G. Homology between the primary structures of $\beta$-lactoglobulins and human retinol binding protein: Evidence for a similar biological function? Biol. Chem. Hoppe Seyler 1985, 366, 431-434. [CrossRef] [PubMed]

5. Pervaiz, S.; Brew, K. Homology and structure-function correlations between $\alpha-1$-acid glycoprotein and serum retinol-binding protein and its relatives. FASEB J. 1987, 1, 209-214. [CrossRef] [PubMed]

6. .Flower, D.R. The lipocalin protein family-Structure and function. Biochem. J. 1996, 318, 1-14. [CrossRef] [PubMed]

7. Bocskei, Z.; Groom, C.R.; Flower, D.R.; Wright, C.E.; Phillips, S.E.V.; Cavaggioni, A.; Findlay, J.B.C.; North, A.C.T. Pheromone binding to two rodent urinary proteins revealed by X-ray crystallography. Nature 1992, 360, 186-188. [CrossRef] [PubMed]

8. Holden, H.M.; Rypniewski, W.R.; Law, J.H.; Rayment, I. The molecular-structure of insecticyanin from the tobacco hornworm manduca-sexta 1 at $2.6 \AA$ resolution. EMBO J. 1987, 6, 1565-1570. [CrossRef]

9. Chaudhuri, B.N.; Kleywegt, G.J.; Bjorkman, J.; Lehman-McKeeman, L.D.; Oliver, J.D.; Jones, A.T. The structures of alpha $(2 \mathrm{u})$-globulin and its complex with a hyaline droplet inducer. Acta Crystallogr. Sect. D Biol. Crystallogr. 1999, 55, 753-762. [CrossRef]

10. Loch, J.I.; Polit, A.; Bonarek, P.; Olszweska, D.; Kurpiewska, K.; Dziedzicka-Wasylewska, M.; Lewiński, K. Structural and thermodynamic studies of binding saturated fatty acids to bovine $\beta$-lactoglobulin. Int. J. Biol. Macromol. 2012, 50, 1095-1102. [CrossRef]

11. Kontopidis, G.; Holt, C.; Sawyer, L. $\beta$-Lactoglobulin: Binding properties, structure, and function. J. Dairy Sci. 2004, 87, 785-796. [CrossRef]

12. Muresan, S.; van der Bent, A.; de Wolf, F.A. Interaction of $\beta$-lactoglobulin with small hydrophobic ligands as monitored by fluorometry and equilibrium dialysis: Nonlinear quenching effects related to protein-Protein association. J. Agric. Food Chem. 2001, 49, 2609-2618. [CrossRef] [PubMed]

13. Keppler, J.K.; Sönnichsen, F.D.; Lorenzen, P.C.; Scharz, K. Differences in heat stability and ligand binding among $\beta$-lactoglobulin genetic variants $\mathrm{A}, \mathrm{B}$ and $\mathrm{C}$ using $1 \mathrm{H}$ NMR and fluorescence quenching. Biochim. Biophys. Acta 2014, 1844, 1083-1093. [CrossRef] [PubMed]

14. Gutiérrez-Magdaleno, G.; Bello, M.; Portillo-Téllez, M.C.; Rodríguez-Romero, A.; García-Hernández, E. Ligand binding and self-association cooperativity of $\beta$-lactoglobulin. J. Mol. Recognit. 2013, 26, 67-75. [CrossRef]

15. Ge, J.; Yue, X.; Wang, S.; Chi, J.; Liang, J.; Sun, Y.; Gao, X.; Yue, P. Nanocomplexes composed of chitosan derivatives and $\beta$-lactoglobulin as a carrier for anthocyanins: Preparation, stability and bioavailability in vitro. Food Res. Int. 2019, 116, 336-345. [CrossRef]

16. Świątek, S.; Komorek, P.; Turner, G.; Jachimska, B. $\beta$-Lactoglobulin as a potential carrier for bioactive molecules. Bioelectrochemistry 2019, 126, 137-145. [CrossRef]

17. Bonarek, P.; Loch, J.I.; Tworzydło, M.; Cooper, D.R.; Milto, K.; Wróbel, P.; Kurpiewska, K.; Lewiński, K. Structure-based design approach to rational site-directed mutagenesis of $\beta$-lactoglobulin. J. Struct. Biol. 2020, 210, 107493. [CrossRef]

18. Farrell, H.M., Jr.; Behe, M.J.; Enyeart, J.A. Binding of p-nitrophenyl phosphate and other aromatic compounds by $\beta$-lactoglobulin. J. Dairy Sci. 1987, 70, 252-258. [CrossRef]

19. Gaye, P.; Denamur, R. Preferential synthesis of $\beta$-lactoglobulin by the bound polyribosomes of the mammary gland. Biochem. Biophys. Res. Commun. 1970, 41, 266-272. [CrossRef]

20. Yoshikawa, M.; Mizukami, T.; Sasaki, R.; Chiba, H. Pre- $\beta$-lactoglobulin synthesis by mRNA from bovine mammary gland. Agric. Biol. Chem. 1978, 42, 2185-2186. 
21. Bairoch, A.; Apweiler, R. The SWISS-PROT protein sequence database and its supplement TREMBL in 2000. Nucleic Acids Res. 2000, 28, 45-48. [CrossRef]

22. Ferranti, P.; Mamone, G.; Picariello, G.; Addeo, F. The "dark side" of $\beta$-lactoglobulin: Unedited structural features suggest unexpected functions. J. Chrom. A 2011, 1218, 3423-3431. [CrossRef] [PubMed]

23. Sasaki, M.; Eigel, W.N.; Keenan, T.W. Lactose and major milk proteins are present in secretory vesicle-rich fractions from lactating mammary gland. Proc. Natl. Acad. Sci. USA 1978, 75, 5020-5024. [CrossRef] [PubMed]

24. Mepham, T.B.; Gayer.; Martin, P.; Mercier, J.C. Biosynthesis of milk protein. In Advanced Dairy Chemistry I. Proteins, 2nd ed.; Fox, P.F., Ed.; Elsevier: Amsterdam, The Netherlands; New York, NY, USA, 1992; pp. 491-543.

25. Hennighausen, L.; Robinson, G.W.; Wagner, K.U.; Liu, X. Prolactin signaling in mammary gland development. J. Biol. Chem. 1997, 272, 7567-7569. [CrossRef] [PubMed]

26. Palmer, A.H. The preparation of a crystalline globulin from the albumin fraction of cow's milk. J. Biol. Chem. 1934, 104, 359-372.

27. Boye, J.I.; Ma, C.Y.; Ismail, A. Thermal stability of beta-lactoglobulins A and B: Effect of SDS, urea, cysteine and N-ethylmaleimide. J. Dairy Res. 2004, 71, 207-215. [CrossRef]

28. Brownlow, S.; Cabral, J.H.M.; Cooper, R.; Flower, D.R.; Yewdall, S.J.; Polikarpov, I.; North, A.C.T.; Sawyer, L. Bovine beta-lactoglobulin at 1.8 angstrom resolution-Still an enigmatic lipocalin. Structure 1997, 5, 481-495. [CrossRef]

29. Hoffmann, M.A.M.; Sala, G.; Olieman, C.; de Kruif, K.G. Molecular mass distributions of heat-induced beta-lactoglobulin aggregates. J. Agric. Food Chem. 1997, 45, 2949-2957. [CrossRef]

30. Qin, B.Y.; Creamer, L.K.; Baker, E.N.; Jameson, G.B. 12-Bromododecanoic acid binds inside the calyx of bovine beta-lactoglobulin. FEBS Lett. 1998, 438, 272-278. [CrossRef]

31. Berman, H.M.; Westbrook, J.; Feng, Z.; Gilliland, G.; Bhat, T.N.; Weissig, H.; Shindyalov, I.N.; Bourne, P.E. The Protein Data Bank. Nucleic Acids Res. 2000, 28, 235-242. [CrossRef]

32. Swaisgood, H.E. Chemistry of milk proteins. In Developments in Dairy Chemistry; Fox, P.F., Ed.; Applied Science Publishers: London, UK, 1982; pp. 1-59.

33. Aschaffenburg, R.; Drewry, R. Occurrence of different beta-lactoglobulins in cow's milk. Nature 1955, 176, 218-219. [CrossRef] [PubMed]

34. Braunitzer, G.; Chen, R.; Schrank, B.; Stangl, A. The sequence of beta-lactoglobulin (Author's transl). Hoppe Seyler's Z. Physiol. Chem. 1973, 354, 867-878. [CrossRef]

35. Gough, P.; Jenness, R. Heat denaturation of $\beta$-lactoglobulins A and B. J. Dairy Sci. 1962, 45, 1033-1039. [CrossRef]

36. Imafidon, G.I.; Ng-Kwai-Hang, K.F.; Harwalkar, V.R.; Ma, C.Y. Effect of genetic polymorphism on the thermal stability of $\beta$-lactoglobulin and k-casein mixture. J. Dairy Sci. 1991, 74, 1791-1802. [CrossRef]

37. Manderson, G.A.; Hardman, M.J.; Creamer, L.K. Effect of heat treatment on the conformation and aggregation of $\beta$-lactoglobulin A, B, and C. J. Agric. Food Chem. 1998, 46, 5052-5061. [CrossRef]

38. Creamer, L.K.; Nilsson, H.C.; Paulsson, M.A.; Coker, C.J.; Hill, J.P.; Jiménez-Flores, R. Effect of genetic variation on the tryptic hydrolysis of bovine $\beta$-lactoglobulin A, B, and C. J. Dairy Sci. 2004, 87, 4023-4032. [CrossRef]

39. Bell, J.A.; Beck, M.D.; Huebner, R.J. Epidemiologic studies of Q fever in Southern California. J. Am. Med. Assoc. 1950, 142, 868-872. [CrossRef]

40. Belitz, H.D.; Grosch, W.; Schieberle, P. Chapter 10. Milk and Dairy Products. In Food Chemistry, 4th ed.; Springer: Berlin, Germany, 2009; pp. 517-518.

41. Mercadante, D.; Melton, L.; Norris, G.; Loo, T.; Williams, M.; Dobson, R.; Jameson, G. Bovine $\beta$-lactoglobulin is dimeric under imitative physiological conditions: Dissociation equilibrium and rate constants over the $\mathrm{pH}$ range of 2.5-7.5. Biophys. J. 2011, 103, 303-312. [CrossRef]

42. Crowther, J.M.; Allison, J.R.; Smolenski, G.A.; Hodgkinson, A.J.; Jameson, G.B.; Dobson, R.C.J. The self-association and thermal denaturation of caprine and bovine $\beta$-lactoglobulin. Eur. Biophys. J. 2018, 47, 739-750. [CrossRef] [PubMed]

43. Kuwata, K.; Era, S.; Hoshino, M.; Forge, V.; Goto, Y.; Batt, C. Solution structure and dynamics of bovine $\beta$-lactoglobulin A. Protein Sci. 1999, 8, 2541-2545. [CrossRef] 
44. Uhrínová, S.; Smith, M.H.; Jameson, G.B.; Uhrín, D.; Sawyer, L.; Barlow, P.N. Structural changes accompanying $\mathrm{pH}$-induced dissociation of the beta-lactoglobulin dimer. Biochemistry 2000, 39, 3565-3574. [CrossRef]

45. Seo, J.A.; Hédoux, A.; Guinet, Y.; Paccou, L.; Affouard, F.; Lerbret, A.; Descamps, M. Thermal denaturation of beta-lactoglobulin and stabilization mechanism by trehalose analyzed from raman spectroscopy investigations. J. Phys. Chem. B 2010, 114, 6675-6684. [CrossRef] [PubMed]

46. Townend, R.; Herskovits, T.T.; Timasheff, S.N.; Gorbunoff, M.T. The state of amino acid residues in $\beta$-lactoglobulin. Arch. Biochem. Biophys. 1969, 129, 567-580. [CrossRef]

47. Kella, N.K.D.; Kinsella, J.E. Structural stability of $\beta$-lactoglobulin in the presence of kosmotropic salts, a kinetic and a thermodynamic study. Int. J. Pept. Protein Res. 1988, 32, 396-405. [CrossRef] [PubMed]

48. Ptitsyn, O.B. Molten globule and protein folding. Adv. Protein Chem. 1995, 47, 83-229. [PubMed]

49. .Judy, E.; Kishore, N. A look back at the molten globule state of proteins: Thermodynamic aspects. Biophys. Rev. 2019, 11, 365-375. [CrossRef]

50. Bhattacharjee, C.; Saha, S.; Biswas, A.; Kundu, M.; Ghosh, L.; Das, K.P. Structural changes of $\beta$-lactoglobulin during thermal unfolding and refolding-An FT-IR and circular dichroism study. Prot. J. 2005, 24, 27-35. [CrossRef]

51. Kella, N.K.D.; Kinsella, J.E. Enhanced thermostability of $\beta$-lactoglobulin at low pH. A possible mechanism. Biochem. J. 1988, 225, 113-118. [CrossRef]

52. Surewicz, W.K.; Mantsch, H.H.; Chapman, D. Determination of protein secondary structure by fourier transform infrared spectroscopy: A critical assessment. Biochemistry 1993, 32, 389-394. [CrossRef]

53. De Jongh, H.H.J.; Gröneveld, T.; de Groot, J. Mild isolation procedure discloses new protein structural properties of $\beta$-lactoglobulin. J. Dairy Sci. 2001, 84, 562-571. [CrossRef]

54. Lefèvre, T.; Subirade, M. Structural and interaction properties of $\beta$-lactoglobulin as studied by FTIR spectroscopy. Int. J. Food Sci. Technol. 1999, 34, 419-428. [CrossRef]

55. Qi, X.L.; Holt, C.; McNulty, D.; Clarke, D.T.; Brownlow, S.; Jones, G.R. Effect of temperature on the secondary structure of $\beta$-lactoglobulin at $\mathrm{pH} 6.7$, as determined by CD and IR spectroscopy: A test of the molten globule hypothesis. Biochem. J. 1997, 324, 341-346. [CrossRef] [PubMed]

56. Sawyer, W.H. Heat denaturation of bovine $\beta$-lactoglobulins and relevance of disulfide aggregation. J. Dairy Sci. 1968, 51, 323-329. [CrossRef]

57. Watanabe, K.; Klostermeyer, H. Heat-induced changes in sulphydryl and disulfide levels of $\beta$-lactoglobulin A and the formation of polymers. J. Dairy Res. 1976, 43, 411-418. [CrossRef]

58. Hillier, R.M.; Lyster, R.L.J.; Cheeseman, G.C. Gelation of reconstituted whey powders by heat. J. Sci. Food Agric. 1980, 31, 1152-1157. [CrossRef]

59. Shimada, K.; Cheftel, J.C. Sulfhydryl group/disulfide bond interchange reactions during heat-induced gelation of whey protein isolate. J. Agric. Food Chem. 1989, 37, 161-168. [CrossRef]

60. Liu, T.X.; Relkin, P.; Launay, B. Thermal denaturation of heat-induced gelation properties of $\beta$-lactoglobulin. Effects of some chemical parameters. Thermochim. Acta 1994, 246, 387-403. [CrossRef]

61. McSwiney, M.; Singh, H.; Campanella, O.H. Thermal aggregation and gelation of bovine $\beta$-lactoglobulin. Food Hydrocoll. 1994, 8, 441-453. [CrossRef]

62. McSwiney, M.; Singh, H.; Campanella, O.H.; Creamer, L.K. Thermal gelation and denaturation of bovine $\beta$-lactoglobulins A and B. J. Dairy Res. 1994, 61, 221-232. [CrossRef]

63. Iametti, S.; Cairoli, S.; De Gregori, B.; Bonomi, F. Modification of high order structures upon heating of $\beta$-lactoglobulin: Dependence on the protein concentration. J. Agric. Food Chem. 1995, 43, 53-58. [CrossRef]

64. Roefs, S.P.F.M.; De Kruif, C.G. A model for the denaturation and aggregation of $\beta$-lactoglobulin. Eur. J. Biochem. 1994, 226, 883-889. [CrossRef] [PubMed]

65. Michalski, M.C.; Januel, C. Does homogenization affect the human health properties of cow's milk? Trends Food Sci. Technol. 2006, 17, 423-437. [CrossRef]

66. Lee, S.J.; Sherbon, J.W. Chemical changes in bovine milk fat globule membrane caused by heat treatment and homogenization of whole milk. J. Dairy Res. 2002, 69, 555-567. [CrossRef] [PubMed]

67. Qi, P.X.; Ren, D.; Xiao, Y.; Tomasula, P.M. Effect of homogenization and pasteurization on the structure and stability of whey protein in milk. J. Dairy Sci. 2015, 98, 2884-2897. [CrossRef] [PubMed]

68. Tunick, M.H.; Ren, D.X.; Van Hekken, D.L.; Bonnaillie, L.; Paul, M.I.; Kwoczak, R.; Tomasula, P.M. Effect of heat and homogenization on in vitro digestion of milk. J. Dairy Sci. 2016, 99, 4124-4139. [CrossRef] [PubMed] 
69. Van Aken, G.A. Relating food emulsion structure and composition to the way it is processed in the gastrointestinal tract and physiological responses: What are the opportunities? Food Biophys. 2010, 5, 258-283. [CrossRef]

70. Munch, G.; Schicktanz, D.; Behme, A.; Gerlach, M.; Riederer, P.; Palm, D.; Schinzel, R. Amino acid specificity of glycation and protein-AGE crosslinking reactivities determined with a dipeptide SPOT library. Nat. Biotechnol. 1999, 17, 1006-1010. [CrossRef]

71. Hodge, J.E. Chemistry of browning reactions in model systems. J. Agric. Food Chem. 1953, 1, $928-943$. [CrossRef]

72. Mossine, V.V.; Glinsky, G.V.; Feather, M.S. The preparation and characterization of some Amadori compounds (1-amino-1-deoxy-D-fructose derivatives) derived from a series of aliphatic $\omega$-amino acids. Carbohydr. Res. 1994, 262, 257-270. [CrossRef]

73. Röper, H.; Röper, S.; Heyns, K.; Meyer, B.N.M.R. spectroscopy of N-(1-deoxy-D-fructos-1-yl)-L amino acids ("fructose-amino acids"). Carbohydr. Res. 1983, 116, 183-195. [CrossRef]

74. Fogliano, V.; Monti, S.M.; Visconti, A.; Randazzo, G.; Facchiano, A.M.; Colonna, G.; Ritieni, A. Identification of a $\beta$-lactoglobulin lactosylation site. Biochim. Biophys. Acta 1998, 1388, 295-304. [CrossRef]

75. Meltretter, J.; Wüst, J.; Pischetsrieder, M. Modified peptides as indicators for thermal and nonthermal reactions in processed milk. J. Agric. Food Chem. 2014, 62, 10903-10915. [CrossRef] [PubMed]

76. Gasparini, A.; Buhler, S.; Faccini, A.; Sforza, S.; Tedeschi, T. Thermally-induced lactosylation of whey proteins: Identification and synthesis of lactosylated $\beta$-lactoglobulin epitope. Molecules 2020, 25, 1294. [CrossRef]

77. Brands, C.M.J.; van Boekel, M.A.J.S. Reactions of monosaccharides during heating of sugar-Casein systems: Building of a reaction network model. J. Agric. Food Chem. 2001, 49, 4667-4675. [CrossRef]

78. Czerwenka, C.; Maier, I.; Pittner, F.; Lindner, W. Investigation of the lactosylation of whey proteins by liquid chromatography-Mass spectrometry. J. Agric. Food Chem. 2006, 54, 8874-8882. [CrossRef]

79. Morgan, F.; Bouhallab, S.; Molle, D.; Henry, G.; Maubois, J.L.; Leonil, J. Lactolation of $\beta$-lactoglobulin monitored by electrospray ionisation mass spectrometry. Int. Dairy J. 1998, 8, 95-98. [CrossRef]

80. Fenaille, F.; Morgan, F.; Parisod, V.; Tabet, J.C.; Guy, P.A. Solid-state glycation of $\beta$-lactoglobulin by lactose and galactose: Localization of the modified amino acids using mass spectrometric techniques. J. Mass Spectrom. 2004, 39, 16-28. [CrossRef]

81. Morgan, F.; Molle, D.; Henry, G.; Venien, A.; Leonil, J.; Peltre, G.; Levieux, D.; Maubois, J.L.; Bouhallab, S. Glycation of bovine $\beta$-lactoglobulin: Effect on the protein structure. Int. J. Food Sci. Technol. 1999, 34, 429-435. [CrossRef]

82. Brands, S.M.J.; van Boekel, M.A.J.S. Kinetic modelling of reactions in heated monosaccharide-casein systems. J. Agric. Food Chem. 2002, 50, 6725-6739. [CrossRef] [PubMed]

83. Endo, Y.; Nagai, H.; Watanabe, Y.; Ochi, K.; Takagi, T. Heat-induced aggregation of recombinant erythropoietin in the intact and deglycosylated states as monitored by gel permeation chromatography combined with a low-angle laser light scattering technique. J. Biochem. 1992, 112, 700-706. [CrossRef] [PubMed]

84. Marshall, J.J.; Rabinowitz, M.L. Preparation and characterization of a dextran-trypsin conjugate. J. Biol. Chem. 1976, 251, 1081-1087. [PubMed]

85. Meldgaard, M.; Svendsen, I. Different effects of N-glycosylation on the thermostability of highly homologous bacterial (1,3-1,4)- $\beta$-glucanases secreted from yeast. Microbiology 1994, 140, 159-166. [CrossRef] [PubMed]

86. Wang, C.; Eufemi, M.; Turano, C.; Giartosio, A. Influence of the carbohydrate moiety on the stability of glycoproteins. Biochemistry 1996, 35, 7299-7307. [CrossRef]

87. Broersen, K.; Voragen, A.G.; Hamer, R.J.; De Jongh, H.H. Glycoforms of beta-lactoglobulin with improved thermostability and preserved structural packing. Biotechnol. Bioeng. 2004, 86, 78-87. [CrossRef] [PubMed]

88. Medrano, A.; Abirached, C.; Panizzolo, L.; Moyna, P.; Anon, M.C. The effect of glycation on foam and structural properties of $\beta$-lactoglobulin. Food Chem. 2009, 113, 127-133. [CrossRef]

89. Mulsow, B.; Jacob, M.; Henle, T. Studies on the impact of glycation on the denaturation of whey proteins. Eur. Food Res. Technol. 2009, 228, 643-649. [CrossRef]

90. Liu, G.; Zhong, Q. Thermal aggregation properties of whey protein glycated with various saccharides. Food Hydrocol. 2013, 32, 87-96. [CrossRef]

91. Broersen, K.; Elshof, M.; De Groot, J.; Voragen, A.G.; Hamer, R.J.; De Jongh, H.H. Aggregation of beta-lactoglobulin regulated by glucosylation. J. Agric. Food Chem. 2007, 55, 2431-2437. [CrossRef] 
92. Van Teeffelen, A.M.; Broersen, K.; de Jongh, H.H. Glucosylation of beta-lactoglobulin lowers the heat capacity change of unfolding; a unique way to affect protein thermodynamics. Protein Sci. 2005, 14, 2187-2194. [CrossRef]

93. Zhao, D.; Zhang, X.; Xu, D.; Su, G.; Li, B.; Li, C. Heat-induced amyloid-like aggregation of $\beta$-lactoglobulin affected by glycation by $\alpha$-dicarbonyl compounds in a model study. J. Sci. Food Agric. 2020, 100, 607-613. [CrossRef]

94. Pinto, M.D.; Bouhallab, S.; De Carvalho, A.F.; Henry, G.; Putaux, J.L.; Leonil, J. Glucose slows down the heat-induced aggregation of beta-lactoglobulin at neutral pH. J. Agric. Food Chem. 2012, 60, 214-219. [CrossRef] [PubMed]

95. Zhao, D.; Li, L.; Xu, D.; Sheng, B.; Chen, J.; Li, B.; Zhang, X. Heat-induced amyloid-like aggregation of $\beta$-lactoglobulin regulated by glycation: A comparison of five kinds of reducing saccharides. Int. J. Biol. Macromol. 2018, 120, 302-309. [CrossRef]

96. Liu, G.; Zhong, Q.X. Glycation of whey protein to provide steric hindrance against thermal aggregation. J. Agric. Food Chem. 2012, 60, 9754-9762. [CrossRef] [PubMed]

97. Dave, A.C.; Loveday, S.M.; Anema, S.G.; Jameson, G.B.; Singh, H. Glycation as a tool to probe the mechanism of $\beta$-lactoglobulin nanofibril self-assembly. J. Agric. Food Chem. 2014, 62, 3269-3278. [CrossRef] [PubMed]

98. Hardy, J.; Selkoe, D.J. The amyloid hypothesis of Alzheimer's disease: Progress and problems on the road to therapeutics. Science 2002, 297, 353-356. [CrossRef] [PubMed]

99. Eisenberg, D.; Jucker, M. The amyloid state of proteins in human diseases. Cell 2012, 148, 1188-1203. [CrossRef]

100. Jucker, M.; Walker, L.C. Self-propagation of pathogenic protein aggregates in neurodegenerative diseases. Nature 2013, 501, 45-51. [CrossRef]

101. Knowles, T.P.J.; Vendruscolo, M.; Dobson, C.M. The amyloid state and its association with protein misfolding diseases. Nat. Rev. Mol. Cell Biol. 2014, 15, 384-396. [CrossRef]

102. Chiti, F.; Dobson, C.M. Protein misfolding, amyloid formation, and human disease: A summary of progress over the last decade. Ann. Rev. Biochem. 2017, 86, 27-68. [CrossRef]

103. Chiti, F.; Taddei, N.; Bucciantini, M.; White, P.; Ramponi, G.; Dobson, C.M. Mutational analysis of the propensity for amyloid formation by a globular protein. EMBO J. 2000, 19, 1441-1449. [CrossRef]

104. Dobson, C.M. The structural basis of protein folding and its links with human disease. Philos. Trans. R. Soc. Lond. B Biol. Sci. 2001, 356, 133-145. [CrossRef] [PubMed]

105. Uversky, V.N.; Fink, A.L. Conformational constraints for amyloid fibrillation: The importance of being unfolded. Biochim. Biophys. Acta 2004, 1698, 131-153. [CrossRef]

106. Schokker, E.P.; Singh, H.; Pinder, D.N.; Creamer, L.K. Heat-induced aggregation of $\beta$-lactoglobulin AB at pH 2.5 as influenced by ionic strength and protein concentration. Int. Dairy J. 2000, 10, 233-240. [CrossRef]

107. Elshereef, R.; Budman, H.; Moresoli, C.; Legge, R.L. Fluorescence spectroscopy as a tool for monitoring solubility and aggregation behavior of beta-lactoglobulin after heat treatment. Biotechnol. Bioeng. 2006, 95, 863-874. [CrossRef] [PubMed]

108. Loveday, S.M.; Wang, X.L.; Rao, M.A.; Anema, S.G.; Creamer, L.K.; Singh, H. Tuning the properties of $\beta$-lactoglobulin nanofibrils with $\mathrm{pH}, \mathrm{NaCl}$ and $\mathrm{CaCl}_{2}$. Int. Dairy J. 2010, 20, 571-579. [CrossRef]

109. Bromley, E.H.C.; Krebs, M.R.H.; Donald, A.M. Mechanisms of structure formation in particulate gels of $\beta$-lactoglobulin formed near the isoelectric point. Eur. Phys. J. E 2006, 21, 145-152. [CrossRef]

110. Langton, M.; Hermansson, A.M. Fine-stranded and particulate gels of $\beta$-lactoglobulin and whey protein at varying pH. Food Hydrocoll. 1992, 5, 523-539. [CrossRef]

111. Krebs, M.R.H.; Devlin, G.L.; Donald, A.M. Amyloid fibril-like structure underlies the aggregate structure across the $\mathrm{pH}$ range for $\beta$-lactoglobulin. Biophys. J. 2009, 96, 5013-5019. [CrossRef]

112. Gosal, W.J.; Clark, A.H.; Pudney, D.A.; Ross-Murphy, S.B. Novel amyloid fibrillar networks derived from a globular protein: $\beta$-lactoglobulin. Langmuir 2002, 18, 7174-7181. [CrossRef]

113. Akkermans, C.; Venema, P.; van der Goot, A.J.; Gruppen, H.; Bakx, E.J.; Boom, R.M.; van der Linden, E. Peptides are building blocks of heat-induced fibrillar protein aggregates of beta-lactoglobulin formed at $\mathrm{pH}$ 2. Biomacromolecules 2008, 9, 1474-1479. [CrossRef]

114. Van den Akker, C.C.; Schleeger, M.; Bonn, M.; Koenderink, G.H. Chapter 31: Structural basis for the polymorphism of $\beta$-lactoglobulin amyloid-like fibrils. In Bio-Nanoimaging_Protein Misfolding and Aggregation; Uversky, V.N., Luybchenko, Y.L., Eds.; Academic Press: Cambridge, MA, USA, 2014; pp. 333-343. 
115. Chen, W.L.; Hwang, M.T.; Liau, C.Y.; Ho, J.C.; Hong, K.C.; Mao, S.J. Beta-lactoglobulin is a thermal marker in processed milk as studied by electrophoresis and circular dichroic spectra. J. Dairy Sci. 2005, 88, 1618-1630. [CrossRef]

116. Roth-Walter, F.; Berin, M.C.; Arnaboldi, P.; Escalante, C.R.; Dahan, S.; Rauch, J.; Jensen-Jarolim, E.; Mayer, L. Pasteurization of milk proteins promotes allergic sensitization by enhancing uptake through Peyer's patches. Allergy 2008, 63, 882-890. [CrossRef] [PubMed]

117. Hines, M.E.; Foegeding, E.A. Interactions of $\alpha$-lactalbumin and bovine serum albumin with $\beta$-lactoglobulin in thermally induced gelation. J. Agric. Food Chem. 1993, 41, 341-346. [CrossRef]

118. Corredig, M.; Dalgleish, D.G. Effect of temperature and $\mathrm{pH}$ on the interactions of whey proteins with casein micelles in skim milk. Food Res. Int. 1996, 29, 49-55. [CrossRef]

119. Haque, Z.; Kinsella, J.E. Interaction between heated $\mathrm{k}$-casein and $\beta$-lactoglobulin: Predominance of hydrophobic interactions in the initial stage of complex formation. J. Dairy Res. 1988, 55, 67-80. [CrossRef]

120. Jang, H.D.; Swaisgood, H.E. Disulfide bond formation between thermally denatured $\beta$-lactoglobulin and k-casein micelles. J. Dairy Sci. 1990, 74, 900-904. [CrossRef]

121. Shalabi, S.I.; Wheelock, J.V. The role of $\alpha$-lactalbumin in the primary phase of chymosin action on heated casein micelles. J. Dairy Res. 1976, 43, 331-335. [CrossRef]

122. Brew, K.; Grobler, J.A. $\alpha$-Lactalbumin. In Advanced Dairy Chemistry; Fox, P.F., Ed.; Springer: Boston, MA, USA, 1992; Volume 1, pp. 191-229.

123. Ramakrishnan, B.; Qasba, P.K. Crystal structure of lactose synthase reveals a large conformational change in its catalytic component, the $\beta 1$,4-galactosyltransferase-I. J. Mol. Biol. 2001, 310, 205-218. [CrossRef]

124. Baumy, J.J.; Brule, G. Binding of bivalent-cations to $\alpha$-lactalbumin and $\beta$-lactoglobulin-Effect of $\mathrm{pH}$ and ionic strength. Lait 1988, 68, 33-48. [CrossRef]

125. Relkin, P. Thermal unfolding of $\beta$-lactoglobulin, $\alpha$-lactalbumin and bovine serum albumin. A thermodynamical approach. Crit. Rev. Food Sci. Nutr. 1996, 36, 565-601. [CrossRef]

126. Jegouic, M.; Grinberg, V.Y.; Guingant, A.; Haertlé, T. Baric oligomerization in $\alpha$-lactalbumin/ $\beta$-lactoglobulin mixtures. J. Agric. Food Chem. 1997, 45, 19-22. [CrossRef]

127. Dickinson, E.; Matsumura, Y. Time-dependent polymerization of $\beta$-lactoglobulin through disulfide bonds at the oil-water interface in emulsions. Int. J. Biol. Macromol. 1991, 13, 26-30. [CrossRef]

128. Monahan, F.J.; McClements, D.J.; Kinsella, J.E. Polymerization of whey proteins in whey protein-stabilized emulsions. J. Agric. Food Chem. 1993, 41, 1826-1829. [CrossRef]

129. Bogahawaththa, D.; Chandrapala, J.; Vasiljevic, T. Thermal denaturation of bovine $\beta$-lactoglobulin in different protein mixtures in relation to antigenicity. Int. Dairy J. 2019, 19, 89-97. [CrossRef]

130. Havea, P.; Singh, H.; Creamer, L.K. Characterization of heat-induced aggregates of $\beta$-lactoglobulin, $\alpha$-lactalbumin and bovine serum albumin in a whey protein concentrate environment. J. Dairy Res. 2001, 68, 483-497. [CrossRef] [PubMed]

131. Schokker, E.P.; Singh, H.; Creamer, L.K. Heat-induced aggregation of $\beta$-lactoglobulin A and B with $\alpha$-lactalbumin. Int. Dairy J. 2000, 10, 843-853. [CrossRef]

132. Hong, Y.; Creamer, L. Changed protein structures of bovine $\beta$-lactoglobulin B and $\alpha$-lactalbumin as a consequence of heat treatment. Int. Dairy J. 2002, 12, 345-359. [CrossRef]

133. Bolder, S.G.; Hendrickx, H.; Sagis, L.M.C.; van der Linden, E. Fibril assemblies in aqueous whey protein mixtures. J. Agric. Food Chem. 2006, 54, 4229-4234. [CrossRef] [PubMed]

134. Holt, C.; Horne, D.S. The hairy casein micelle: Evolution of the concept and its implications for dairy technology. Neth. Milk Dairy J. 1996, 50, 85e111.

135. Creamer, L.K.; Plowman, J.E.; Liddell, M.J.; Smith, M.H.; Hill, J.P. Micelle stability: Kappa-casein structure and function. J. Dairy Sci. 1998, 81, 3004-3012. [CrossRef]

136. Zittle, C.A.; Thompson, M.P.; Custer, J.H.; Cerbulis, J. k-Casein- $\beta$-lactoglobulin interaction in solution when heated. J. Dairy Sci. 1962, 45, 807-810. [CrossRef]

137. Dalgleish, D.G. Denaturation and aggregation of serum proteins and caseins in heated milk. J. Agric. Food Chem. 1990, 38, 1996-1999. [CrossRef]

138. Law, A.J.R.; Banks, J.M.; Horne, D.S.; Leaver, J.; West, I.G. Denaturation of the whey protein in heated milk and their incorporation into Cheddar cheese. Milchwissenschaft 1994, 49, 63-67.

139. Noh, B.; Creamer, L.K.; Richardson, T. Thermally induced complex formation in an artificial milk system. J. Agric. Food Chem. 1989, 37, 1395-1400. [CrossRef] 
140. Noh, B.; Richardson, T.; Creamer, L.K. Radiolabelling study of the heat-induced interactions between $\alpha$-lactalbumin, $\beta$-lactoglobulin and k-casein in milk and buffer solutions. J. Food Sci. 1989, 54, 889-893. [CrossRef]

141. Sawyer, W.H.; Coulter, S.T.; Jenness, R. Role of sulfhydryl groups in the interaction of $\mathrm{k}$-casein and $\beta$-lactoglobulin. J. Dairy Sci. 1963, 46, 564-565. [CrossRef]

142. Lowe, E.K.; Anema, S.G.; Bienvenue, A.; Boland, M.J.; Creamer, L.K.; Jiménez-Flores, R. Heat-induced redistribution of disulfide bonds in milk proteins. 2. Disulfide bonding patterns between bovine $\beta$-lactoglobulin and k-casein. J. Agric. Food Chem. 2004, 52, 7669-7680. [CrossRef]

143. Livney, Y.D.; Dalgleish, D.G. Specificity of disulfide bond formation during thermal aggregation in solutions of $\beta$-lactoglobulin B and $\mathrm{k}$-casein A. J. Agric. Food Chem. 2004, 52, 5527-5532. [CrossRef]

144. Oldfield, D.J.; Singh, H.; Taylor, M.W. Association of $\beta$-lactoglobulin and $\alpha$-lactalbumin with the casein micelles in skim milk heated in an ultra-high temperature plant. Int. Dairy J. 1998, 8, 765-770. [CrossRef]

145. Cho, Y.; Singh, H.; Creamer, L.K. Heat-induced interactions of beta-lactoglobulin A and kappa-casein B in a model system. J. Dairy Res. 2003, 70, 61-71. [CrossRef]

146. Anema, S.G. On heating milk, the dissociation of $\mathrm{k}$-casein from the casein micelles can precede interactions with the denatured whey proteins. J. Dairy Res. 2008, 75, 415-421. [CrossRef]

147. McKenzie, G.H.; Norton, R.S.; Sawyer, W.H. Heat-induced interaction of $\beta$-lactoglobulin and $\kappa$-casein. J. Dairy Res. 1971, 38, 343-351. [CrossRef]

148. Creamer, L.K.; Bienvenue, A.; Nilsson, H.; Paulsson, M.; van Wanroij, M.; Lowe, E.K.; Anema, S.G.; Boland, M.J.; Jiménez-Flores, R. Heat-induced redistribution of disulfide bonds in milk proteins. 1. Bovine beta-lactoglobulin. J. Agric. Food Chem. 2004, 52, 7660-7668. [CrossRef] [PubMed]

149. Euber, J.R.; Brunner, J.R. Interaction of k-casein with immobilized $\beta$-lactoglobulin. J. Dairy Sci. 1982, 65, 2384-2387. [CrossRef]

150. Chevalier, F.; Hirtz, C.; Sommerer, N.; Kelly, A.L. Use of reducing/nonreducing two-dimensional electrophoresis for the study of disulfide-mediated interactions between proteins in raw and heated bovine milk. J. Agric. Food Chem. 2009, 57, 5948-5955. [CrossRef]

151. Donato, L.; Guyomarc'h, F. Formation and properties of the whey protein $/ \kappa$-casein complexes in heated skim milk-A review. Dairy Sci. Technol. 2009, 89, 3-29. [CrossRef]

152. Mather, I.H. A review and proposed nomenclature for major proteins of the milk-fat globule membrane. J. Dairy Sci. 2000, 83, 203-247. [CrossRef]

153. Fong, B.Y.; Norris, C.S.; MacGibbon, A.K.H. Protein and lipid composition of bovine milk-fat-globule membrane. Int. Dairy J. 2007, 17, 275-288. [CrossRef]

154. Corredig, M.; Dalgleish, D.G. Isolates from industrial buttermilk: Emulsifying properties of materials derived from the milk fat globule membrane. J. Agric. Food Chem. 1997, 45, 4595-4600. [CrossRef]

155. Damodaran, S. Amino acids, peptides, and proteins. 217-329. In Fennema's Food Chemistry, 4th ed.; Damodaran, S., Parkin, K.L., Fennema, O.R., Eds.; CRC Press: Boca Raton, FL, USA, 2007.

156. Zhang, S.; Vardhanabhuti, B. Effect of initial protein concentration and $\mathrm{pH}$ on in vitro gastric digestion of heated whey proteins. Food Chem. 2014, 145, 473-480. [CrossRef]

157. Ryle, A.P.; Auffret, C.A. The specificity of some pig and human pepsins toward synthetic peptide substrates. Biochem. J. 1979, 179, 247-249. [CrossRef] [PubMed]

158. Oliveira, K.M.G.; Valente-Mesquita, V.L.; Botelho, M.M.; Sawyer, L.; Ferreira, S.T.; Polikarpov, I. Crystal structures of bovine $\beta$-lactoglobulin in the orthorhombic space group $\mathrm{C} 222_{1}$-Structural differences between genetic variants A and B and features of the Tanford transition. Eur. J. Biochem. 2001, 268, 477-482. [CrossRef] [PubMed]

159. Fox, P.F.; McSweeney, P.L.H. Advanced Dairy Chemistry, 3rd ed.; Kluwer Academic: New York, NY, USA; Plenum Publishers: New York, NY, USA, 2013; Volume 1, Part A.

160. Bossios, A.; Theodoropoulou, M.; Mondoulet, L.; Rigby, N.M.; Papadopoulos, N.G.; Bernard, H.; Adel-Patient, K.; Wal, J.M.; Mills, C.E.N.; Papageorgiou, P. Effect of simulated gastro-duodenal digestion on the allergenic reactivity of beta-lactoglobulin. Clin. Transl. Allergy 2011, 1, 6. [CrossRef] [PubMed]

161. Sélo, I.; Clément, G.; Bernard, H.; Chatel, J.; Créminon, C.; Peltre, G.; Wal, J. Allergy to bovine beta-lactoglobulin: Specificity of human IgE to tryptic peptides. Clin. Exp. Allergy 1999, 29, 1055-1063. [CrossRef] [PubMed] 
162. Egger, L.; Ménard, O.; Delgado-Andrade, C.; Alvito, P.; Assunção, R.; Balance, S.; Barberá, R.; Brodkorb, A.; Cattenoz, T.; Clemente, A.; et al. The harmonized INFOGEST in vitro digestion method: From knowledge to action. Food Res. Int. 2016, 88, 217-225. [CrossRef]

163. Kopf-Bolanz, K.A.; Schwander, F.; Gijs, M.; Vergères, G.; Portmann, R.; Egger, L. Impact of milk processing on the generation of peptides during digestion. Int. Dairy J. 2014, 35, 130-138. [CrossRef]

164. Fu, T.J.; Abbott, U.R.; Hatzos, C. Digestibility of food allergens and nonallergenic proteins in simulated gastric fluid and simulated intestinal fluid-a comparative study. J. Agric. Food Chem. 2002, 50, 7154-7160. [CrossRef]

165. Schmidt, D.G.; Meijer, R.J.; Slangen, C.J.; van Beresteijn, E.C. Raising the pH of the pepsin-catalysed hydrolysis of bovine whey proteins increases the antigenicity of the hydrolysates. Clin. Exp. Allergy 1995, 25, 1007-1017. [CrossRef]

166. Mandalari, G.; Adel-Patient, K.; Barkholt, V.; Baro, C.; Bennett, L.; Bublin, M.; Gaier, S.; Graser, G.; Ladics, G.S.; Mierzejewska, D.; et al. In vitro digestibility of $\beta$-casein and $\beta$-lactoglobulin under simulated human gastric and duodenal conditions: A multi-laboratory evaluation. Regul. Toxicol. Pharmacol. 2009, 55, 372-381. [CrossRef]

167. Sousa, R.; Portmann, R.; Dubois, S.; Recio, I.; Egger, L. Protein digestion of different protein sources using the INFOGEST static digestion model. Food Res. Int. 2020, 130, 108996. [CrossRef]

168. Peram, M.R.; Loveday, S.M.; Ye, A.; Singh, H. In vitro gastric digestion of heat-induced aggregates of $\beta$-lactoglobulin. J. Dairy Sci. 2013, 96, 63-74. [CrossRef] [PubMed]

169. Moreno, F.J.; Mackie, A.R.; Mills, E.N. Phospholipid interactions protect the milk allergen alpha-lactalbumin from proteolysis during in vitro digestion. J. Agric. Food Chem. 2005, 53, 9810-9816. [CrossRef] [PubMed]

170. Verhoeckx, K.; Cotter, P.; López-Expósito, I.; Kleiveland, C.; Lea, T.; Mackie, A.; Requena, T.; Swiatecka, D.; Wichers, H. The Impact of Food Bioactives on Health: In Vitro and Ex Vivo Models; Springer International Publishing: Cham, Switzerland, 2015; pp. 73-81.

171. Egger, L.; Ménard, O.; Baumann, C.; Duerr, D.; Schlegel, P.; Stoll, P.; Vergères, G.; Dupont, D.; Portmann, R. Digestion of milk proteins: Comparing static and dynamic in vitro digestion systems with in vivo data. Food Res. Int. 2019, 118, 32-39. [CrossRef] [PubMed]

172. Gasteiger, E.; Hoogland, C.; Gattiker, A.; Duvaud, S.; Wilkins, M.R.; Appel, R.D.; Bairoch, A. Protein Identification and Analysis Tools on the ExPASy Server. In The Proteomics Protocols Handbook; Walker, J.M., Ed.; Humana Press: Totowa, NJ, USA, 2005.

173. Van Lieshout, G.A.A.; Lambers, T.T.; Bragt, M.C.E.; Hettinga, K.A. How processing may affect milk protein digestion and overall physiological outcomes: A systematic review. Crit. Rev. Food Sci. Nutr. 2019, 1-24. [CrossRef]

174. Chobert, J.M.; Briand, L.; Grinberg, V.; Haertlé, T. Impact of esterification on the folding and the susceptibility to peptic proteolysis of $\beta$-lactoglobulin. Biochim. Biophys. Acta 1995, 1248, 170-176. [CrossRef]

175. Dalgalarrondo, M.; Dufour, E.; Chobert, J.M.; Bertrand-Harb, C.; Haertlé, T. Proteolysis of $\beta$-lactoglobulin and $\beta$-casein by pepsin in ethanolic media. Int. Dairy J. 1995, 5, 1-14. [CrossRef]

176. Guo, M.R.; Fox, P.F.; Flynn, A.; Kindstedt, P.S. Susceptibility of $\beta$-lactoglobulin and sodium caseinate to proteolysis by pepsin and trypsin. J. Dairy Sci. 1995, 78, 2336-2344. [CrossRef]

177. Selvaggini, C.; De Gioia, L.; Cantù, L.; Ghibaudi, E.; Diomede, L.; Passerini, F.; Forloni, G.; Bugiani, O.; Tagliavini, F.; Salmona, M. Molecular characteristics of a protease-resistant, amyloidogenic and neurotoxic peptide homologous to residues 106-126 of the prion protein. Biochem. Biophys. Res. Commun. 1993, 194, 1380-1386. [CrossRef]

178. Simōes, L.S.; Martins, J.T.; Pinheiro, A.C.; Vicente, A.A.; Ramos, O.L. $\beta$-lactoglobulin micro- and nanostructures as bioactive compounds vehicle: In vitro studies. Food Res. Int. 2020, 131, 108979. [CrossRef]

179. Bateman, L.; Ye, A.; Singh, H. In vitro digestion of $\beta$-lactoglobulin fibrils formed by heat treatment at low pH. J. Agric. Food Chem. 2010, 58, 9800-9808. [CrossRef]

180. Bateman, L.; Ye, A.; Singh, H. Re-formation of fibrils from hydrolysates of $\beta$-lactoglobulin fibrils during in vitro gastric digestion. J. Agric. Food Chem. 2011, 59, 9605-9611. [CrossRef] [PubMed]

181. Giamblanco, N.; Janot, J.M.; Gubbiotti, A.; Chinappi, M.; Balme, S. Characterization of food amyloid protein digestion by conical nanopore. Small Methods 2020, 9, 1900703. [CrossRef]

182. Keil, B. Specificity of Proteolysis; Springer: Berlin, Germany; New York, NY, USA, 1992; p. 335. 
183. Moughan, P.J.; Rutherfurd, S.M. A new method for determining digestible reactive lysine in foods. J. Agric. Food Chem. 1996, 44, 2202-2209. [CrossRef]

184. Rutherfurd, S.M.; Moughan, P.J. Application of a new method for determining digestible reactive lysine to variably heated protein sources. J. Agric. Food Chem. 1997, 45, 1582-1586. [CrossRef]

185. Rérat, A.; Calmes, R.; Vaissade, P.; Finot, P.A. Nutritional and metabolic consequences of the early Maillard reaction of heat treated milk in the pig. Eur. J. Nutr. 2002, 41, 1-11. [CrossRef]

186. Desrosiers, T.; Savoie, L.; Bergeron, G.; Parent, G. Estimation of lysine damage in heated whey proteins by furosine determinations in conjunction with the digestion cell technique. J. Agric. Food Chem. 1989, 37, 1385-1391. [CrossRef]

187. Sanz, M.L.; Corzo-Martínez, M.; Rastall, R.A.; Olano, A.; Moreno, F.J. Characterization and in vitro digestibility of bovine $\beta$-lactoglobulin glycated with galactooligosaccharides. J. Agric. Food Chem. 2007, 55, 7916-7925. [CrossRef]

188. Corzo-Martínez, M.; Soria, A.C.; Belloque, J.; Villamiel, M.; Moreno, F.J. Effect of glycation on the gastrointestinal digestibility and immunoreactivity of bovine $\beta$-lactoglobulin. Int. Dairy J. 2010, 20, 742-752. [CrossRef]

189. Pinto, M.S.; Léonil, J.; Henry, G.; Cauty, C.; Carvalho, A.F.; Bouhallab, S. Heating and glycation of $\beta$-lactoglobulin and $\beta$-casein: Aggregation and in vitro digestion. Food Res. Int. 2014, 55, 70-76. [CrossRef]

190. Zenker, H.E.; van Lieshout, G.A.A.; van Gool, M.P.; Bragt, M.C.E.; Hettinga, K.A. Lysine blockage of milk proteins in infant formula impairs overall protein digestibility and peptide release. Food Funct. 2020, 11, 358-369. [CrossRef]

191. Çelebioğlu, H.Y.; Lee, S.; Chronakis, I.S. Interactions of salivary mucins and saliva with food proteins: A review. Crit. Rev. Food Sci. Nutr. 2020, 60, 64-83. [CrossRef] [PubMed]

192. Marczynski, M.; Rickert, C.A.; Semerdzhiev, S.A.; Van Dijk, W.R.; Segers-Nolten, I.M.J.; Claessens, M.M.A.E.; Lieleg, O. $\alpha$-Synuclein penetrates mucin hydrogels despite its mucoadhesive properties. Biomacromolecules 2019, 20, 4332-4344. [CrossRef] [PubMed]

193. Round, A.N.; Rigby, N.M.; Garcia de la Torre, A.; Macierzanka, A.; Mills, E.N.C.; Mackie, A.R. Lamellar structures of MUC2-rich mucin: A potential role in governing the barrier and lubricating functions of intestinal mucus. Biomacromolecules 2012, 13, 3253-3261. [CrossRef] [PubMed]

194. Bajka, B.H.; Rigby, N.M.; Cross, K.L.; Macierzanka, A.; Mackie, A.R. The influence of small intestinal mucus structure on particle transport ex vivo. Colloids Surf. B Biointerfaces 2015, 135, 73-80. [CrossRef] [PubMed]

195. Golovkina, T.V.; Shlomchik, M.; Hannum, L.; Chervonsky, A. Organogenic role of B lymphocytes in mucosal immunity. Science 1999, 286, 1965-1968. [CrossRef]

196. Chabot, S.; Wagner, J.S.; Farrant, S.; Neutra, M.R. TLRs regulate the gatekeeping functions of the intestinal follicle-associated epithelium. J. Immunol. 2006, 176, 4275-4283. [CrossRef]

197. Rios, D.; Woodl, M.B.; Li, J.; Chassaing, B.; Gewirtz, A.T.; Williams, I.R. Antigen sampling by intestinal M cells is the principal pathway initiating mucosal IgA production to commensal enteric bacteria. Mucosal Immunol. 2016, 9, 907-916. [CrossRef]

198. Santos, L.M.; al-Sabbagh, A.; Londono, A.; Weiner, H.L. Oral tolerance to myelin basic protein induces regulatory TGF- $\beta$-secreting T cells in Peyer's patches of SJL mice. Cell. Immunol. 1994, 157, 439-447. [CrossRef]

199. Gonnella, P.A.; Chen, Y.; Inobe, J.; Komagata, Y.; Quartulli, M.; Weiner, H.L. In situ immune response in gut-associated lymphoid tissue (GALT) following oral antigen in TCR-transgenic mice. J. Immunol. 1998, 160, $4708-4718$.

200. .Khoury, S.J.; Hancock, W.W.; Weiner, H.L. Oral tolerance to myelin basic protein and natural recovery from experimental autoimmune encephalomyelitis are associated with downregulation of inflammatory cytokines and differential upregulation of transforming growth factor beta, interleukin 4, and prostaglandin E expression in the brain. J. Exp. Med. 1992, 176, 1355-1364.

201. Jung, C.; Hugot, J.P.; Barreau, F. Peyer's patches: The immune sensors of the intestine. Int. J. Inflamm. 2010, 2010, 823710. [CrossRef]

202. Lo, D.; Tynan, W.; Dickerson, J.; Scharf, M.; Cooper, J.; Byrne, D.; Brayden, D.; Higgins, L.; Evans, C.; O'Mahony, D.J. Cell culture modeling of specialized tissue: Identification of genes expressed specifically by follicle-associated epithelium of Peyer's patch by expression profiling of Caco-2/Raji co-cultures. Int. Immunol. 2004, 16, 91-99. [CrossRef] [PubMed] 
203. Hase, K.; Kawano, K.; Nochi, T.; Pontes, G.S.; Fukuda, S.; Ebisawa, M.; Kadokura, K.; Tobe, T.; Fujimura, Y.; Kawano, S.; et al. Uptake through glycoprotein 2 of $\mathrm{FimH}^{+}$bacteria by $\mathrm{M}$ cells initiates mucosal immune response. Nature 2009, 462, 226-230. [CrossRef] [PubMed]

204. Gebert, A.; Steinmetz, I.; Fassbender, S.; Wendlandt, K.H. Antigen transport into Peyer's patches: Increased uptake by constant numbers of M cells. Am. J. Pathol. 2004, 164, 65-72. [CrossRef]

205. Dillon, A.; Lo, D.D. M cells: Intelligent engineering of mucosal immune surveillance. Front. Immunol. 2019, 10, 1499. [CrossRef]

206. Da Silva, C.; Wagner, C.; Bonnardel, J.; Gorvel, J.P.; Lelouard, H. The Peyer's patch mononuclear phagocyte system at steady state and during infection. Front. Immunol. 2017, 8, 1254. [CrossRef]

207. Reboldi, A.; Cyster, J.G. Peyer's patches: Organizing B-cell responses at the intestinal frontier. Immunol. Rev. 2016, 271, 230-245. [CrossRef]

208. Nagata, S.; McKenzie, C.; Pender, S.L.; Bajaj-Elliott, M.; Fairclough, P.D.; Walker-Smith, J.A.; Monteleone, G.; MacDonald, T.T. Human Peyer's patch T cells are sensitized to dietary antigen and display a Th cell type 1 cytokine profile. J. Immunol. 2000, 165, 5315-5321. [CrossRef]

209. Ebert, E.C.; Roberts, A.I. Lamina propria lymphocytes produce interferon-gamma and develop suppressor activity in response to lactoglobulin. Dig. Dis. Sci. 2001, 46, 661-667. [CrossRef]

210. Gollob, J.A.; Li, J.; Reinherz, E.L.; Ritz, J. CD2 regulates responsiveness of activated T cells to interleukin 12. J. Exp. Med. 1995, 182, 721-731. [CrossRef]

211. Ajuebor, M.N.; Das, A.M.; Virág, L.; Flower, R.J.; Szabó, C.; Perretti, M. Role of resident peritoneal macrophages and mast cells in chemokine production and neutrophil migration in acute inflammation: Evidence for an inhibitory loop involving endogenous IL-10. J. Immunol. 1999, 162, 1685-1691. [PubMed]

212. Sadik, C.D.; Kim, N.D.; Luster, A.D. Neutrophils cascading their way to inflammation. Trends Immunol. 2011, 32, 452-460. [CrossRef] [PubMed]

213. Amulic, B.; Cazalet, C.; Hayes, G.L.; Metzler, K.D.; Zychlinsky, A. Neutrophil function: From mechanisms to disease. Annu. Rev. Immunol. 2012, 30, 459-489. [CrossRef] [PubMed]

214. Rusu, D.; Drouin, R.; Pouliot, Y.; Gauthier, S.; Poubelle, P.E. A bovine whey protein extract stimulates human neutrophils to generate bioactive IL-1Ra through a NF-kappaB- and MAPK-dependent mechanism. J. Nutr. 2010, 140, 382-391. [CrossRef] [PubMed]

215. Rusu, D.; Drouin, R.; Pouliot, Y.; Gauthier, S.; Poubelle, P.E. A bovine whey protein extract can enhance innate immunity by priming normal human blood neutrophils. J. Nutr. 2009, 139, 386-393. [CrossRef]

216. Dusi, S.; Della Bianca, V.; Grzeskowiak, M.; Rossi, F. Relationship between phosphorylation and translocation to the plasma membrane of p47phox and p67phox and activation of the NADPH oxidase in normal and $\mathrm{Ca}^{2+}$-depleted human neutrophils. Biochem. J. 1993, 290, 173-178. [CrossRef] 